\title{
15. DEWATERING OF SEDIMENTS ALONG THE CASCADIA MARGIN: EVIDENCE FROM GEOTECHNICAL PROPERTIES ${ }^{1}$
}

\author{
Peter Hempel ${ }^{2}$
}

\begin{abstract}
The lithologic composition and bulk physical properties of sediments recovered by Kasten coring at 29 sites in the Cascadia Margin give insight into the processes of tectonic dewatering from the Pleistocene to the present. Shear strength and water content, in particular, reveal the degree to which tectonic influence has modified the sediments. The undeformed sediments of the abyssal plain have low shear strength and high water contents throughout the maximum cored depths of $3 \mathrm{~m}$. In contrast, sediments at the base of the slope are characterized by extremely high shear strength and low water contents. Between these two end members, sediments from the deformation ridges on the continental margin show intermediate shear strength and water content values. There is a close relationship between the water content/porosity and the degree of sediment diagenesis. High water contents are restricted to silty to clayey intervals of minor consolidation, whereas low water contents appear in the cemented sandy to silty layers. Patterns of fluid migration in the near-surface section are inferred from these data and from pore water chemistry. Calculated rates of fluid expulsion at the seafloor are $2 \times 10^{-4} \mathrm{~L} / \mathrm{m}^{2} /$ day $\left(2.3 \times 10^{-12} \mathrm{~m}^{3} / \mathrm{m}^{2} / \mathrm{s}\right)$. The results suggest that fluid expulsion is higher off central Oregon compared to the area off southern Washington.

Based on the bulk mineralogical composition of the sediments examined and some grain-size analyses, I conclude that generation of the consolidated layers is closely related to the dewatering processes, a widespread phenomenon along the Cascadia Margin evidenced in "vent" fields.
\end{abstract}

\section{INTRODUCTION}

The deformation history of accretionary prisms and its effects on the physical properties of the sediments, geochemistry of the pore waters, and mechanisms of fluid flow along convergent margins, have received considerable attention over the past 10 years. The importance of these inquiries is most emphatically expressed by the dedication of five drilling legs of the JOIDES Resolution to accretionary prism studies (Leg 110, Barbados accretionary prism [Mascle, Moore, et al., 1988]; Leg 112, Peru margin [Suess, von Huene, et al., 1988]; Leg 131, Nankai Trough [Taira, Hill, Firth, et al., 1991]; Leg 141, Chile Triple Junction [Behrmann, Lewis, Musgrave, et al., 1992], and Leg 146, Cascadia Margin [Westbrook, Carson, Musgrave, et al., 1994]). The results of these drilling campaigns provide insight into tectonic and associated processes that are active within the accretionary prisms. In addition, a number of dives by deep-diving submersibles have provided direct observations of the expulsion of fluids and gases at the seafloor (Carson et al., 1990), as well as the sampling of rocks and cements formed by the interaction of venting fluids with bottom seawater (Ritger et al., 1987; Okada, 1989; Suess and Whiticar, 1989; Kulm and Suess, 1990; LePichon et al., 1992).

Studies along the Cascadia Margin off Oregon and Washington have resulted in one of the most comprehensive data sets of any convergent margin. These data include observations from submersibles and remotely operated camera systems (Kulm et al., 1986; Suess et al.,1985), side-scan sonar data (Carson et al., 1991), "in situ" measurements (Davis et al., 1991), surficial samples recovered by coring and dredging, and seismic reflection lines (MacKay et al., 1992). During cruises of Wecoma in 1983 and Atlantis in 1984 and 1987 sediment cores were recovered along transects perpendicular to the con-

'Carson, B., Westbrook, G.K., Musgrave, R.J., and Suess, E. (Eds.), 1995. Proc. ODP, Sci. Results, 146 (Pt. 1): College Station, TX (Ocean Drilling Program).

${ }^{2}$ GEOMAR, Wischhofstraße 1-3, 24148 Kiel, Federal Republic of Germany. (Current address: HOLINGER Umwelttechnik GmbH, Königsweg 59, 24114 Kiel, Federal Republic of Germany). tinental margin off Oregon and southern Washington. Pore-water analyses of the sediments, recovered by kasten corer and box corer, demonstrated the presence of fluids derived from greater depths and the generation of precipitation products in near-surface sediments (Han, 1987; Han and Suess, 1989; Suess and Whiticar, 1989). In this paper we present the results of physical property measurements and diagenetic investigations of these sediments with the emphasis on their relation to the tectonic history of the Cascadia Margin. The objective of this study is to close the gap between seafloor observations and the drilling results of Ocean Drilling Program (ODP) Leg 146 by (1) delineating the paths of upward-directed fluid flow within the accretionary prism and (2) demonstrating the effects of tectonic deformation and venting on the bulk mineralogy and physical properties of sediments from the youngest geological past.

\section{GEOLOGICAL SETTING}

The Juan de Fuca oceanic plate converges with the North American plate off Oregon and Washington (Fig. 1) at a present-day rate of 40-44 mm per year (Davis and Hyndman, 1989). At the convergent margin, a portion of the sediments on the Juan de Fuca plate is scraped off during subduction and accreted to the North American plate. This process forms the Cascadia accretionary complex along the lower continental slope (Silver, 1972; Carson, 1977; Kulm and Fowler, 1974). The accretionary complex consists of a series of folded and thrusted ridges that generally parallel the edge of the continental shelf (EEZ-Scan 84 Scientific Staff, 1986). The deformation front is the baseline between the undeformed abyssal plain sediments and the tectonically influenced deposits. Landward of the deformation front, numerous ridges verge landward and seaward and become progressively older from the west to the east across the complex; the youngest ridge close the deformation front is less than $0.3 \mathrm{~m}$.y. old (Carson, 1977; Kulm et al., 1986). Along the Cascadia Margin, both overthrusting and underthrusting occur as a result of tectonic deformation. Sediment cores were recovered from areas along four transects spanning the tectonic elements from the abyssal plain across 


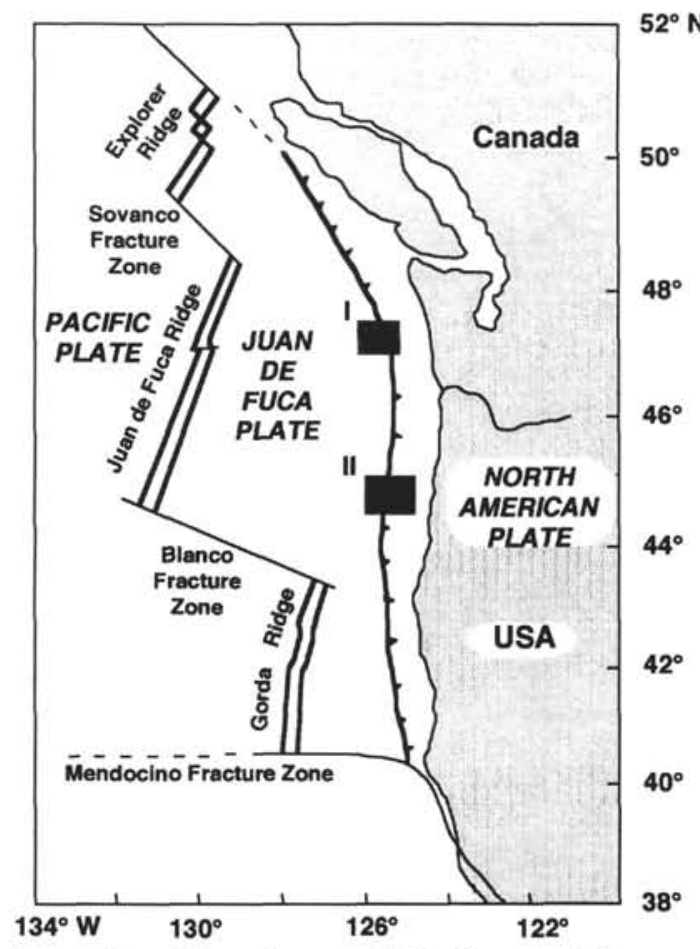

Figure 1. Overview of the study areas off Washington and Oregon with the main plate tectonic features.

landward- and seaward-vergent deformation ridges. The two northern transects (Figs. 2, 3A) are located in the central Washington overthrust area. The central and southern transects are in the overthrust and underthrust area off Oregon respectively (Figs. 2, 3B). The locations of the sampling stations and their surrounding tectonic environment are described in detail by Han and Suess (1989) and are summarized in Table 1.

\section{MATERIAL AND METHODS}

Twenty-nine sediment cores were sampled at the core repository, College of Oceanography, Oregon State University (Corvallis/USA). These cores were recovered from the continental margin off southern Washington and Oregon during two cruises of Wecoma (W8306A and W8306C) in June 1983 and of Atlantis AT8408 and AT8708 in August of 1984 and 1987, respectively. All cores were stored undisturbed for as long as seven years at $4^{\circ} \mathrm{C}$ and were in good condition. Previous studies on these cores were restricted to pore-water chemistry, analyses that were performed on whole-round samples taken directly on board (Han, 1987). The core locations are shown in Figure 2.

The sediments are characterized by fairly homogeneous, soft, hemipelagic muds and oozes with more consolidated layers of silty clay to very fine sand. These consolidated layers prevented, in most places, the penetration of the kasten corer deeper than $3 \mathrm{~m}$. Biogenic components are present only in minor amounts and are restricted to siliceous particles. A total of 459 samples was taken, 114 shear strength measurements were performed, and 402 samples were analyzed for water content and density. These analyses supplement the sparse physical property measurements made on board and result in a $10-\mathrm{cm}$ sample spacing for all cores. Duplicate samples from the same intervals as those sampled on board revealed a difference of less than $10 \%$ (absolute) in water content. Of the 18 samples taken for ${ }^{14} \mathrm{C}$ dating, only three samples had sufficiently high organic carbon contents for this purpose. In addition to the measurement of physical properties and dating of the sediments, the samples were also ana- lyzed for carbonate and organic carbon and a subset of 39 samples was analyzed for mineralogy by X-ray diffraction (XRD). Grain-size analyses on selected samples were restricted to the $<63-\mu \mathrm{m}$ fraction.

The samples were kept refrigerated until they were processed at the GEOMAR laboratory at Kiel. The following measurements were determined on $10-\mathrm{cm}^{3}$ samples, using gravimetric and volumetric determinations: wet-bulk density, dry-bulk density, grain density, porosity, and water content. Measurements of wet and dry weights and volumes allowed us to calculate various related index properties. The wet volume was precisely obtained by cutting the sample with a stainless-steel cylinder with a defined volume of $10 \mathrm{~cm}^{3}$. Wet and dry weights were determined using a Sartorius analytical balance to an accuracy of $\pm 0.01 \mathrm{~g}$. Water content was determined by the weight loss of freeze-dried samples. Wet-bulk density was calculated from the ratio of the weight of the wet-sediment to the wet sediment volume, and dry-bulk density is given by the ratio of the weight of dry sediment to the volume of wet sediment. Grain density was determined independently by weighing the dry sample and measuring the dry volume with a Penta Pycnometer. The results were used to calculate the porosity on the basis of the equations given by Boyce (1976); other calculations follow the conventions of ODP.

Shear strength measurements were performed on undisturbed sections of the working halves of the sediment cores with a motorized shear vane device normal to the bedding planes. A vane $(10 \mathrm{~mm} \times 8$ $\mathrm{mm}$ ) was inserted $1 \mathrm{~cm}$ into the sediment and a torsional stress of 4 $\mathrm{rpm}$ applied to the sample. The shear strength was calculated using the stress at failure and a geometric-size constant for the vane. The values presented are in most cases the mean of two or three measurements performed at one interval.

The carbonate and organic carbon contents were determined on the same samples used for the physical property determinations. The measurements were performed on samples treated with $2 \mathrm{~N} \mathrm{HCL}$ using a LECO CS 244 Carbon Sulphur Analyzer. Measurements with the LECO device yielded the total carbon and organic carbon content of the samples, from which the carbonate content was calculated, by difference. On a set of surface samples recovered by dredging, stable carbon and oxygen isotopes were determined at the mass spectrometer facility of Scripps Institution of Oceanography. The results are listed in Table 2.

Sampling for bulk mineralogical studies focused on cemented layers apparent in numerous cores. All samples were mechanically ground and mixed with an internal standard of corundum $\left(\mathrm{a}-\mathrm{Al}_{2} \mathrm{O}_{3}\right)$ at a ratio of $2: 1$, further grinding in an agate vial with acetone enhanced homogenization. Samples were then prepared as randomly oriented, pressed powder slides and XRD measurements were conducted using a Philips PW 1729 generator and $\mathrm{Co}_{\mathrm{Ka}}$ radiation. The goniometer velocity was set at $0.02^{\circ} 2 \theta / \mathrm{s}$ and scans were run between $2^{\circ}$ and $40^{\circ}$ $2 \theta$. The data were processed using APD-1700 software (Philips) on a Micro PDP 11 computer system.

For the quantification of quartz, the ratio of $d(101)$ of the quartz peak height (at $3.343 \AA$ ) to the $\mathrm{d}(012)$ corundum peak height (at $3.479 \AA$ ) was used. The absolute amount of quartz was then estimated from a standard curve of 11 mixtures of different amounts of quartz with a monomineralic matrix of smectite. Sediment dating was performed with conventional ${ }^{14} \mathrm{C}$ methodology of the organic carbon $\left(\mathrm{C}_{\text {org }}\right)$ on three samples from Core AT8408-11. Because the organic carbon content of the samples is about $1 \%$ of the wet-weight, $250 \mathrm{~g}$ of sediment, covering an interval of $6-8 \mathrm{~cm}$, was required to provide sufficient $\mathrm{C}_{\text {org }}$ for accurate age determinations. The measurements were performed at the ${ }^{14} \mathrm{C}$ Laboratory of Kiel University.

\section{RESULTS}

The tectonic and depositional history of this margin is most evident from seafloor topography and the reflection patterns of high-resolution seismic data. Along the transects across the continental mar- 
A

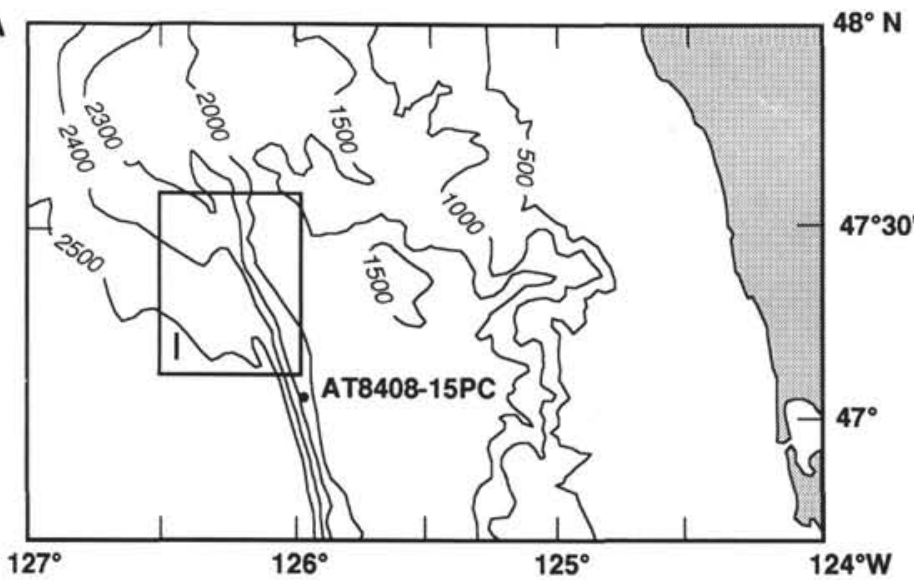

B
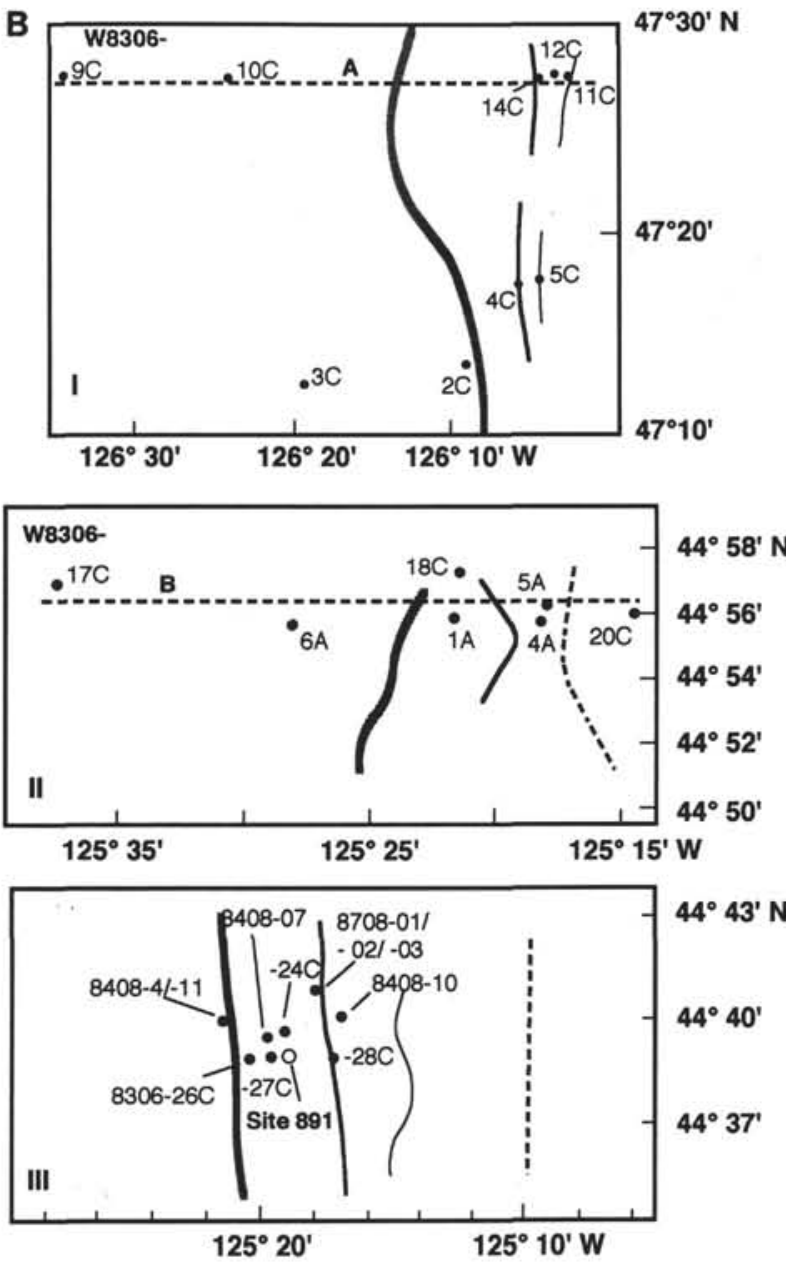

Figure 2. Study areas along the Cascadia Margin as shown by the shaded areas in Figure 1. A. Bathymetry and study areas off Washington and Oregon. Contour interval: $500 \mathrm{~m}$. B. Detailed view of coring localities off Washington (I) and central Oregon (II and III). Wide gray line = location of the present base of slope; solid line = axis of the most seaward deformation ridge; thin line = center of the sediment basin, separating the seaward ridge from the next landward ridge (vertical broken line) (after Han, 1987). Horizontal broken lines = location of the seismic lines, shown in Figure 3.

gin sediment cores were recovered at sites selected from the reflection seismic records. Although a direct link between seismic reflectors and physical properties of the sediment cores can not be drawn, there is an obvious influence of the large-scale deformational processes on the near-surface sediments. Physical property values follow, in general, the structural elements of the continental margin, with significant differences between undeformed and deformed sediments. In general, the physical properties of the sediments indicate a stronger deformation of the sediments within the overthrust area off Washington relative to the underthrust area off Oregon.

\section{Continental Margin off Southern Washington}

The seismic profile across the deformation zone off southern Washington (Figs. 2, 3A) reveals the tectonic elements of the youngest deformation. The depositional sequence west of Core RK-10 (meaning Wecoma Core W8306-10C) is largely undisturbed, as evidenced by the numerous reflectors running parallel to the seafloor (Fig. 3A) and by the sediment physical parameters, such as water content, wet-bulk density, and shear strength depth profiles in Core RK-9C (W8306C-09) (Fig. 4). Single-point excursions from soft, normally consolidated sediments originate in distinct turbiditic hori- zons, which are more highly consolidated and contain higher amounts of the $>63-\mu \mathrm{m}$ fraction.

Core W8306-02C (Fig. 5) sampled a collapsed mud mound at the base of the continental slope, in the vicinity of the deformation front, where the reflection pattern is chaotic (RK-02 in Fig. 3A). The collapse of the mud mound probably led to the complete deterioration of the bedding and additional compaction, resulting in porosities and shear strength values of $50 \%$ and $33 \mathrm{kPa}$, respectively, at a depth of about $40 \mathrm{~cm}$. These values are normally found at burial depths of several hundred meters even at convergent margins (Bray and Karig, 1985).

At the crest of the first deformation ridge there are single, folded reflectors visible in the seismic records (Fig. 3A). This structural deformation suggests tectonic sediment compaction has taken place. Evidence of this compaction is expressed in shear strength values of about $20 \mathrm{kPa}$ at a depth of $1 \mathrm{~m}$ and a porosity of $55 \%$ at $1 \mathrm{~m}$ (Fig. 6).

A sediment basin is located landward of the first and youngest deformation ridge. This and other similar basins are characterized by generally undisturbed deposits, as evidenced by smooth and parallel horizontal reflectors (Fig. 3A), despite the deformed sequences of deeply-rooted folds piercing through the basin fill. Physical property measurements of sediment samples from Core W8306-11C (RK-11 

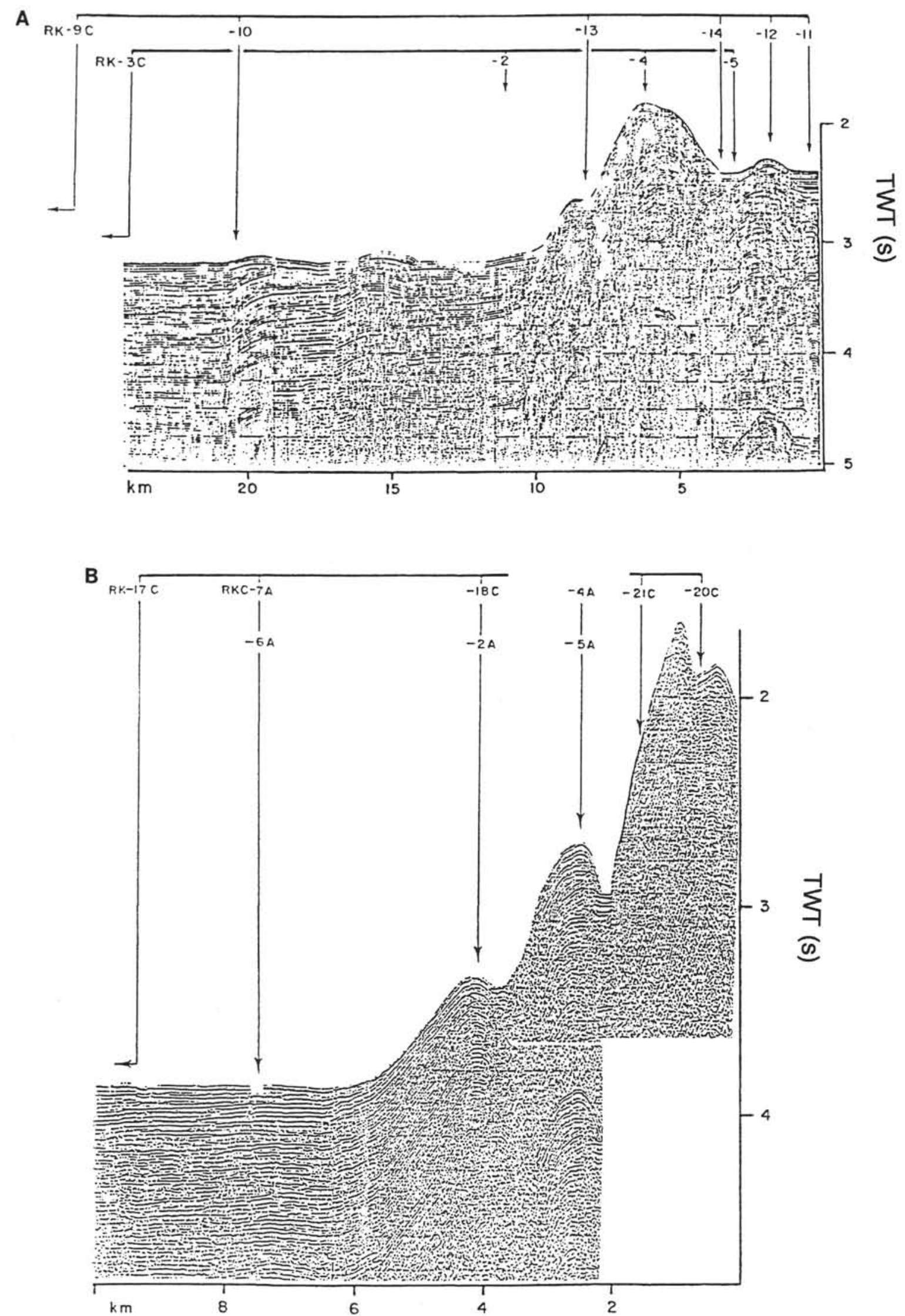

Figure 3. Seismic sections with location of sampling sites across the lower continental slope (A) off Washington and (B) off central Oregon. RK-C and RK-A denote cores taken during Wecoma cruise W8306-A and W8306-C. For references see Figure 2 and Table 1. 
Table 1. Coring site location, water depth, and core recovery.

\begin{tabular}{|c|c|c|c|c|}
\hline Core & Latitude & Longitude & $\begin{array}{l}\text { Water depth } \\
(\mathrm{m})\end{array}$ & $\begin{array}{c}\text { Recovery } \\
\text { (cm) }\end{array}$ \\
\hline \multicolumn{5}{|c|}{ Oregon Margin (overthrust area) } \\
\hline W8306-1A & $44^{\circ} 56.34^{\prime}$ & $125^{\circ} 21.73^{\prime}$ & 2511 & 167 \\
\hline W8306-4A & $44^{\circ} 55.91^{\prime}$ & $125^{\circ} 18.64^{\prime}$ & 2008 & 55 \\
\hline W8306-5A & $44^{\circ} 56.26^{\prime}$ & $125^{\circ} 18.45^{\prime}$ & 1990 & 103 \\
\hline W8306-6A & $44^{\circ} 55.44^{\prime}$ & $125^{\circ} 28.37^{\prime}$ & 2758 & 279 \\
\hline \multicolumn{5}{|c|}{ Washington Margin (mound area) } \\
\hline W8306-2C & $47^{\circ} 13.70^{\prime}$ & $126^{\circ} 08.90^{\prime}$ & 2320 & 70 \\
\hline W8306-3C & $47^{\circ} 12.50^{\prime}$ & $126^{\circ} 19.36^{\prime}$ & 2445 & 170 \\
\hline W8306-4C & $47^{\circ} 17.53^{\prime}$ & $126^{\circ} 05.67^{\prime}$ & 1920 & 135 \\
\hline W8306-5C & $47^{\circ} 17.74^{\prime}$ & $126^{\circ} 04.29^{\prime}$ & 2050 & 200 \\
\hline \multicolumn{5}{|c|}{ Washington Margin (ridge offset area) } \\
\hline W8306-9C & $47^{\circ} 27.51^{\prime}$ & $126^{\circ} 34.55^{\prime}$ & 2370 & 270 \\
\hline W8306-10C & $47^{\circ} 27.42^{\prime}$ & $126^{\circ} 23.89^{\prime}$ & 2320 & 195 \\
\hline W8306-11C & $47^{\circ} 27.49^{\prime}$ & $126^{\circ} 02.15^{\prime}$ & 1600 & 195 \\
\hline W8306-12C & $47^{\circ} 27.47^{\prime}$ & $126^{\circ} 03.28^{\prime}$ & 1807 & 250 \\
\hline W8306-14C & $47^{\circ} 27.50^{\prime}$ & $126^{\circ} 04.17^{\prime}$ & 1810 & 145 \\
\hline \multicolumn{5}{|c|}{ Transit to Oregon Margin (overthrust area) } \\
\hline W8306-17C & $44^{\circ} 57.00^{\prime}$ & $125^{\circ} 37.92^{\prime}$ & 2735 & 195 \\
\hline W8306-18C & $44^{\circ} 57.45^{\prime}$ & $125^{\circ} 21.96^{\prime}$ & 2376 & 200 \\
\hline W8306-20C & $44^{\circ} 55.98^{\prime}$ & $125^{\circ} 14.87^{\prime}$ & 1260 & 100 \\
\hline \multicolumn{5}{|c|}{ Oregon Margin (underthrust area) } \\
\hline W8306-24C & $44^{\circ} 39.78^{\prime}$ & $125^{\circ} 19.07^{\prime}$ & 2420 & 170 \\
\hline W8306-26C & $44^{\circ} 39.00^{\prime}$ & $125^{\circ} 20.50^{\prime}$ & 2795 & 165 \\
\hline W $8306-27 \mathrm{C}$ & $44^{\circ} 39.00^{\prime}$ & $125^{\circ} 19.66^{\prime}$ & 2623 & 150 \\
\hline W8306-28C & $44^{\circ} 38.99^{\prime}$ & $125^{\circ} 17.41^{\prime}$ & 2014 & 100 \\
\hline AT $8408-4$ & $44^{\circ} 40.00^{\prime}$ & $125^{\circ} 21.60^{\prime}$ & 2860 & 230 \\
\hline AT8408-7 & $44^{\circ} 39.50^{\prime}$ & $125^{\circ} 19.70^{\prime}$ & 2550 & 56 \\
\hline AT $8408-10$ & $44^{\circ} 40.00^{\prime}$ & $125^{\circ} 17.10^{\prime}$ & 2180 & 215 \\
\hline AT8408-11 & $44^{\circ} 39.90^{\prime}$ & $125^{\circ} 21.50^{\prime}$ & 2846 & 120 \\
\hline AT8408-15PC & $47^{\circ} 00.45^{\prime}$ & $125^{\circ} 54.78^{\prime}$ & 2124 & 588 \\
\hline AT8708-1 & $44^{\circ} 40.80^{\prime}$ & $125^{\circ} 17.70^{\prime}$ & 2080 & 115 \\
\hline AT8708-2 & $44^{\circ} 40.80^{\prime}$ & $125^{\circ} 17.46^{\prime}$ & 2091? & 220 \\
\hline AT $8708-3$ & $44^{\circ} 40.80^{\prime}$ & $125^{\circ} 17.46^{\prime}$ & $2040 ?$ & 122 \\
\hline AT $8708-6$ & $45^{\circ} 11.40^{\prime}$ & $125^{\circ} 31.74^{\prime}$ & 2437 & 190 \\
\hline
\end{tabular}

Notes: Core naming conventions: $\mathrm{W}=$ Wecoma, $\mathrm{AT}=$ Atlantis.

in Fig. 7) reflect the undeformed seismic pattern by showing a continuous increase of wet-bulk density $\left(1.32\right.$ to $\left.1.82 \mathrm{~g} / \mathrm{cm}^{3}\right)$ and shear strength to about $10 \mathrm{kPa}$ and a corresponding decrease of porosity from $80 \%$ to $55 \%$ with depth.

\section{Continental Slope off Oregon}

\section{Northern Profile (Overthrust Area)}

From the seismic reflection profile recorded perpendicular to the slope (Figs. 2B and 3B), the different tectonic units can be distinguished clearly in the reflection characteristics and associated physical properties of the sediments. The physical properties are similar to those described above for the Washington deformation zone. Coring localities were selected to sample all of the tectonic zones. Undeformed sediments reveal only minor physical property variations with depth. Sediment Core W8306-18C (RK-18C), recovered from the vicinity of the first deformation ridge, exhibits extreme physical properties even at shallow depth, which is similar to physical properties observed in Core W8306C-02 (Fig. 4) in a similar setting off southern Washington. At a depth of $80 \mathrm{~cm}$ the wet-bulk density of Core W8306-05A increases from 1.5 to $1.9 \mathrm{~g} / \mathrm{cm}^{3}$ (Fig. 8). These values are associated with shear strength values of about $26 \mathrm{kPa}$ and a decrease in porosity to about $38 \%$ (Fig. 8).

\section{Southern Profiles (Underthrust Area)}

Two profiles were sampled across the deformation front and the seaward deformation ridge off central Oregon along $44^{\circ} 40^{\prime} \mathrm{N}$ and $44^{\circ} 39^{\prime} \mathrm{N}$ latitude (Fig. 2B). As was the case in the profiles described above, the physical properties of the near-surface sediments reflect the different tectonic regimes. The strongest tectonic influence is visible in a core (W8306-26C) from the deformation front region, where
Table 2. Oxygen and carbon isotopic values from surficial and coring samples.

\begin{tabular}{|c|c|c|c|c|c|c|}
\hline Sample device & Latitude & Longitude & $\begin{array}{c}\text { Sample } \\
\text { ID }\end{array}$ & $\begin{array}{l}\delta^{n} \mathrm{O} \\
(\%) \text { (\%) }\end{array}$ & $\begin{array}{l}\delta^{13} \mathrm{C} \\
(\% \circ)\end{array}$ & $\begin{array}{l}\mathrm{CaCO}_{3} \\
(\mathrm{wt} \%)\end{array}$ \\
\hline W8306-0IC & $47^{\circ} 13.68^{\prime}$ & $126^{\circ} 08.76^{\prime}$ & $01 / 200$ & -8.20 & -2.07 & 5.60 \\
\hline W8306-02C & $47^{\circ} 13.70^{\prime}$ & $126^{\circ} 08.90^{\prime}$ & $02 / 300$ & -7.70 & -2.74 & 2.80 \\
\hline W8306-03C & $47^{\circ} 12.50^{\prime}$ & $126^{\circ} 19.36^{\prime}$ & $03 / 100$ & -2.88 & 0.26 & 9.50 \\
\hline \multirow[t]{2}{*}{ W8306-05C } & $47^{\circ} 17.74^{\prime}$ & $126^{\circ} 04.29^{\prime}$ & $05 / 100$ & -4.39 & -1.11 & 8.10 \\
\hline & & & $05 / 300$ & -4.06 & -0.94 & 7.50 \\
\hline DR-06 & $47^{\circ} 40.68^{\prime}$ & $126^{\circ} 00.00^{\prime}$ & $06 / 300$ & -7.34 & -0.26 & 1.20 \\
\hline DR-07 & $47^{\circ} 40.68^{\prime}$ & $125^{\circ} 57.96^{\prime}$ & $07 / 300$ & -1.58 & -12.07 & 4.00 \\
\hline DR-07 & & & $07 / 900$ & -8.18 & -1.92 & 2.80 \\
\hline W8306-09C & $47^{\circ} 27.51^{\prime}$ & $125^{\circ} 34.55^{\prime}$ & $09 / 200$ & -11.12 & -2.27 & 7.60 \\
\hline W8306-11C & $47^{\circ} 27.49^{\prime}$ & $126^{\circ} 02.16^{\prime}$ & $11 / 100$ & -1.96 & -19.95 & 7.40 \\
\hline W8306-12C & $47^{\circ} 27.47^{\prime}$ & $126^{\circ} 03.28^{\prime}$ & $12 / 200$ & -4.75 & -1.02 & 7.90 \\
\hline \multirow[t]{2}{*}{ W8306-14C } & $47^{\circ} 27.50^{\prime}$ & $126^{\circ} 04.17^{\prime}$ & $14 / 100$ & -3.14 & -1.26 & 9.70 \\
\hline & & & $14 / 200$ & -5.77 & -0.71 & 7.60 \\
\hline \multirow[t]{19}{*}{ DR-16 } & $44^{\circ} 56.10^{\prime}$ & $125^{\circ} 16.08^{\prime}$ & $16 / 200$ & 4.31 & -51.21 & 63.90 \\
\hline & & & $16 / 300$ & 2.14 & -4.08 & 7.80 \\
\hline & & & $16 / 400$ & -10.17 & -0.44 & 7.40 \\
\hline & & & $16 / 500$ & -11.78 & 0.38 & 4.90 \\
\hline & & & $16 / 600$ & -8.26 & -6.43 & 7.10 \\
\hline & & & $16 / 700$ & -12.22 & -1.51 & 7.60 \\
\hline & & & $16 / 100$ & -12.86 & -0.70 & 5.20 \\
\hline & & & $16 / 110$ & -8.49 & -6.04 & 8.30 \\
\hline & & & $16 / 120$ & -8.50 & -3.12 & 8.50 \\
\hline & & & $16 / 130$ & 3.69 & -48.74 & 27.10 \\
\hline & & & $16 / 150$ & 5.59 & -1.28 & 3.00 \\
\hline & & & $16 / 190$ & -11.65 & -3.38 & 9.30 \\
\hline & & & $16 / 210$ & -7.67 & -1.19 & 2.70 \\
\hline & & & $16 / 220$ & -3.18 & -0.74 & 2.10 \\
\hline & & & $16 / 230$ & -10.82 & -0.29 & 8.00 \\
\hline & & & $16 / 240$ & -11.22 & -1.23 & 10.40 \\
\hline & & & $16 / B$ & -12.05 & -0.93 & 8.10 \\
\hline & & & $16 / \mathrm{C}$ & -9.84 & -1.89 & 8.70 \\
\hline & & & $16 / \mathrm{E}$ & -10.91 & -1.63 & 8.90 \\
\hline W8306-17C & $44^{\circ} 57.00^{\prime}$ & $125^{\circ} 37.92^{\prime}$ & $17 / 35$ & -7.40 & -2.09 & 0.90 \\
\hline \multirow{4}{*}{ W8306-18C } & $44^{\circ} 57.45^{\prime}$ & $125^{\circ} 21.96^{\prime}$ & $18 / 100$ & -4.39 & 0.11 & 7.30 \\
\hline & & & $18 / 30$ & -5.55 & -1.47 & 7.30 \\
\hline & & & $18 / 70$ & -7.80 & -2.07 & 1.10 \\
\hline & & & $18 / 130$ & -7.90 & -1.59 & 0.70 \\
\hline \multirow{10}{*}{ DR-19 } & $44^{\circ} 92.9^{\prime}$ & $125^{\circ} 25^{\prime}$ & $19 / 20$ & -10.18 & -1.68 & 6.00 \\
\hline & & & $19 / 40$ & -8.58 & -1.99 & 6.00 \\
\hline & & & $19 / 60$ & -7.66 & -1.80 & 6.30 \\
\hline & & & $19 / 70$ & -7.88 & -2.24 & 6.50 \\
\hline & & & $19 / 80$ & -7.29 & -1.88 & 6.00 \\
\hline & & & $19 / 90$ & -9.52 & -2.22 & 6.30 \\
\hline & & & $19 / 100$ & -10.31 & -1.11 & 6.00 \\
\hline & & & $19 / 110$ & -10.25 & -1.51 & 5.60 \\
\hline & & & $19 / 120^{\prime}$ & -10.24 & -1.28 & 5.70 \\
\hline & & & $19 / 105$ & -7.82 & -2.35 & 6.20 \\
\hline \multirow{2}{*}{ W8306-21C } & $44^{\circ} 56.10^{\prime}$ & $125^{\circ} 16.15^{\prime}$ & $21 / 15$ & -7.41 & -1.98 & 2.50 \\
\hline & & & $21 / 30$ & -4.20 & -3.07 & 2.60 \\
\hline \multirow{6}{*}{ DR-22 } & $45^{\circ} 00.00^{\prime}$ & $125^{\circ} 27.00^{\prime}$ & $22 / 20$ & 4.22 & -66.30 & 39.30 \\
\hline & & & $22 / 30$ & -3.76 & -11.01 & 26.10 \\
\hline & & & $22 / 60$ & 4.72 & -58.73 & 54.10 \\
\hline & & & $22 / 80$ & -12.01 & -1.31 & 11.60 \\
\hline & & & $22 / 120$ & 2.78 & -66.70 & 35.40 \\
\hline & & & $22 / 13$ & 3.66 & -56.10 & 36.10 \\
\hline DR-23 & $44^{\circ} 40.20^{\prime}$ & $125^{\circ} 19.86^{\prime}$ & $23 / 20$ & -11.02 & -0.91 & 10.70 \\
\hline W8306-24C & $44^{\circ} 39.78^{\prime}$ & $125^{\circ} 19.07^{\prime}$ & $24 / 20$ & -10.04 & -0.58 & 6.70 \\
\hline W8306-25C & $44^{\circ} 39.84^{\prime}$ & $125^{\circ} 18.30^{\prime}$ & $25 / 100$ & -1.91 & -0.75 & 6.10 \\
\hline & & & $25 / 35$ & -6.83 & -1.90 & 3.70 \\
\hline W8306-26C & $44^{\circ} 39.00^{\prime}$ & $125^{\circ} 20.50^{\prime}$ & $26 / 100$ & -6.51 & -0.95 & 6.40 \\
\hline & & & $26 / 92$ & -10.80 & -1.27 & 3.70 \\
\hline W8306-27C & $44^{\circ} 39.00^{\prime}$ & $125^{\circ} 19.66^{\prime}$ & $27 / 70$ & -4.20 & 0.11 & 3.80 \\
\hline DR-29 & $44^{\circ} 39.00^{\prime}$ & $125^{\circ} 19.56^{\prime}$ & $29 / 100$ & -10.36 & -1.83 & 11.80 \\
\hline & & & $29 / 40$ & -10.26 & -1.28 & 5.90 \\
\hline & & & $29 / 50$ & -7.96 & -11.98 & 9.60 \\
\hline & & & $29 / 60$ & -10.70 & -0.29 & 4.70 \\
\hline & & & $29 / 70$ & -11.65 & -0.12 & 7.60 \\
\hline & & & $29 / 80$ & -2.51 & -0.71 & 5.50 \\
\hline & & & $29 / 110$ & -9.09 & 0.28 & 4.30 \\
\hline DR-63 & $44^{\circ} 39.00^{\prime}$ & $125^{\circ} 30.48^{\prime}$ & $63 / 09$ & 6.12 & -51.81 & 62.00 \\
\hline DR-68 & $47^{\circ} 31.20^{\prime}$ & $125^{\circ} 58.38^{\prime}$ & $68 / 14$ & 3.98 & -41.31 & 70.00 \\
\hline DR-7914 & $47^{\circ} 00.00^{\prime}$ & $125^{\circ} 46.80^{\prime}$ & $79 / 14$ & 4.75 & -58.74 & 59.00 \\
\hline DR-7933 & $47^{\circ} 51.60^{\prime}$ & $125^{\circ} 09,36^{\prime}$ & $79 / 33$ & 5.41 & -49.60 & 43.00 \\
\hline DR-7934 & $48^{\circ} 27.96^{\prime}$ & $125^{\circ} 19.80^{\prime}$ & $79 / 34$ & 5.80 & -49.03 & 61.00 \\
\hline DR-9003 & $45^{\circ} 45.48^{\prime}$ & $125^{\circ} 10.98^{\prime}$ & $90 / 03$ & 4.18 & -44.14 & 76.00 \\
\hline DR-9028 & $47^{\circ} 34.20^{\prime}$ & $125^{\circ} 21.96^{\prime}$ & $90 / 28$ & 6.13 & -46.35 & 81.00 \\
\hline
\end{tabular}

Notes: Carbonate contents from Scamman (1981); Sample device: W8306-XX = Kasten corer; $\mathrm{DR}=$ dredge. 


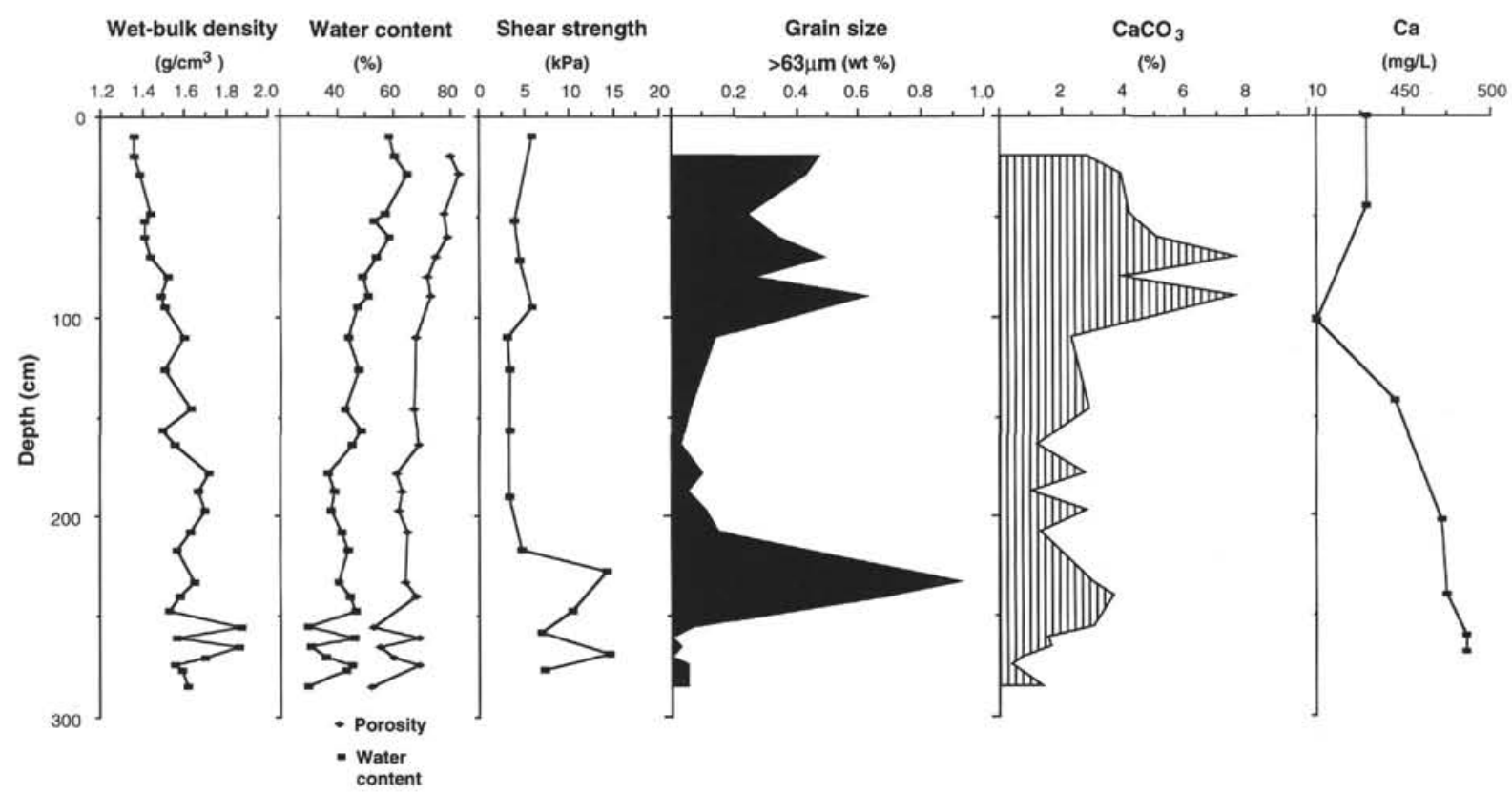

Figure 4. Physical properties of Core W8306C-09 from the abyssal plain with typical values reflecting the pelagic depositional environment. Dissolved calcium values in the pore water are those reported by Han (1987).

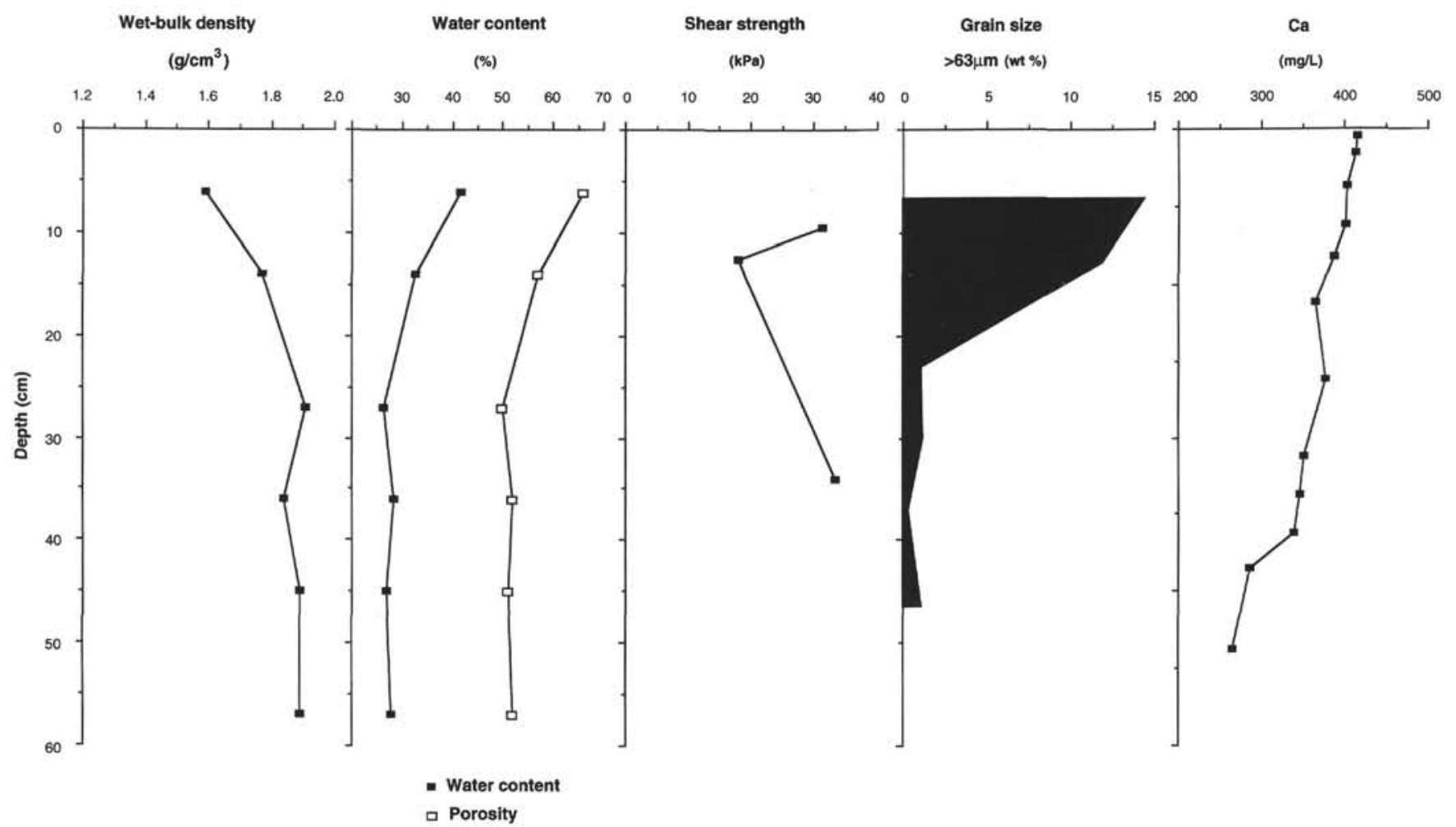

Figure 5. Physical properties of sediment Core W8306C-02 from a mud mound at the deformation front. Note the high shear strength values at shallow depth and the low porosity and water content values. Dissolved calcium values in the pore water are those reported by Han (1987).

the shear strength measurements reached maximum values of $51 \mathrm{kPa}$ at a depth of about $120 \mathrm{~cm}$ (see Appendix on the CD-ROM in the back pocket of this volume). The profiles of the physical properties vs. depth in all cores recovered from the different tectonic settings (W8306C-24, -26, -27, -28, AT8408-04, -07, -10, -11, AT8708-02, and -03 ) are in the same range as those reported from the northern transects above (see Appendix on CD-ROM).
The shear strength and water contents from the different structural elements are summarized in Figures 9 and 10.

\section{Bulk Mineralogy and Carbonate Content}

The aim of the diagenetic investigations was to resolve the composition and genesis of the consolidated layers present in numerous 


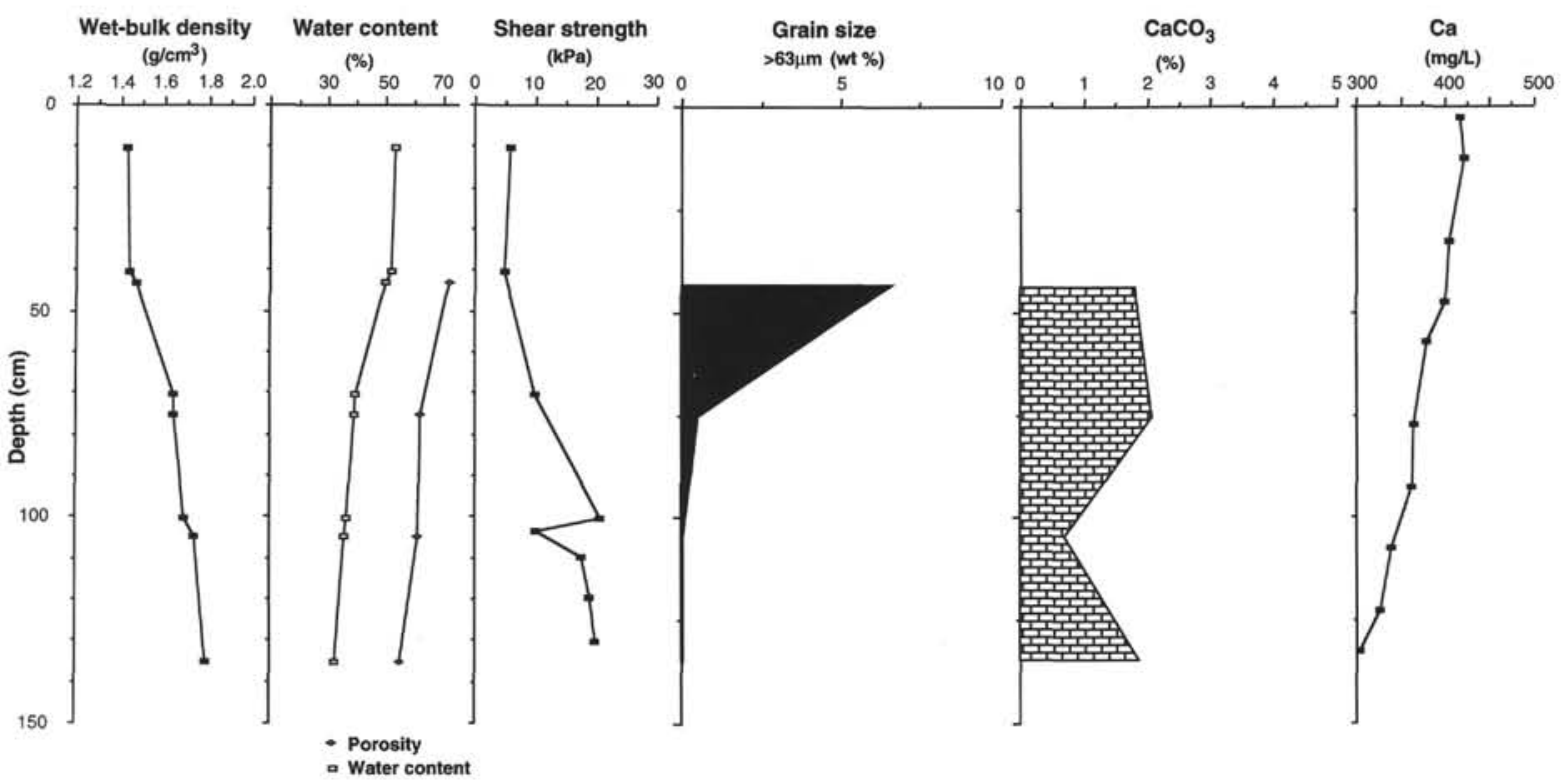

Figure 6. Core W8306C-04 originates from the top the seaward ridge with intermediate shear strength values, porosity, and water content values. Dissolved calcium values in the pore water are those reported by Han (1987).

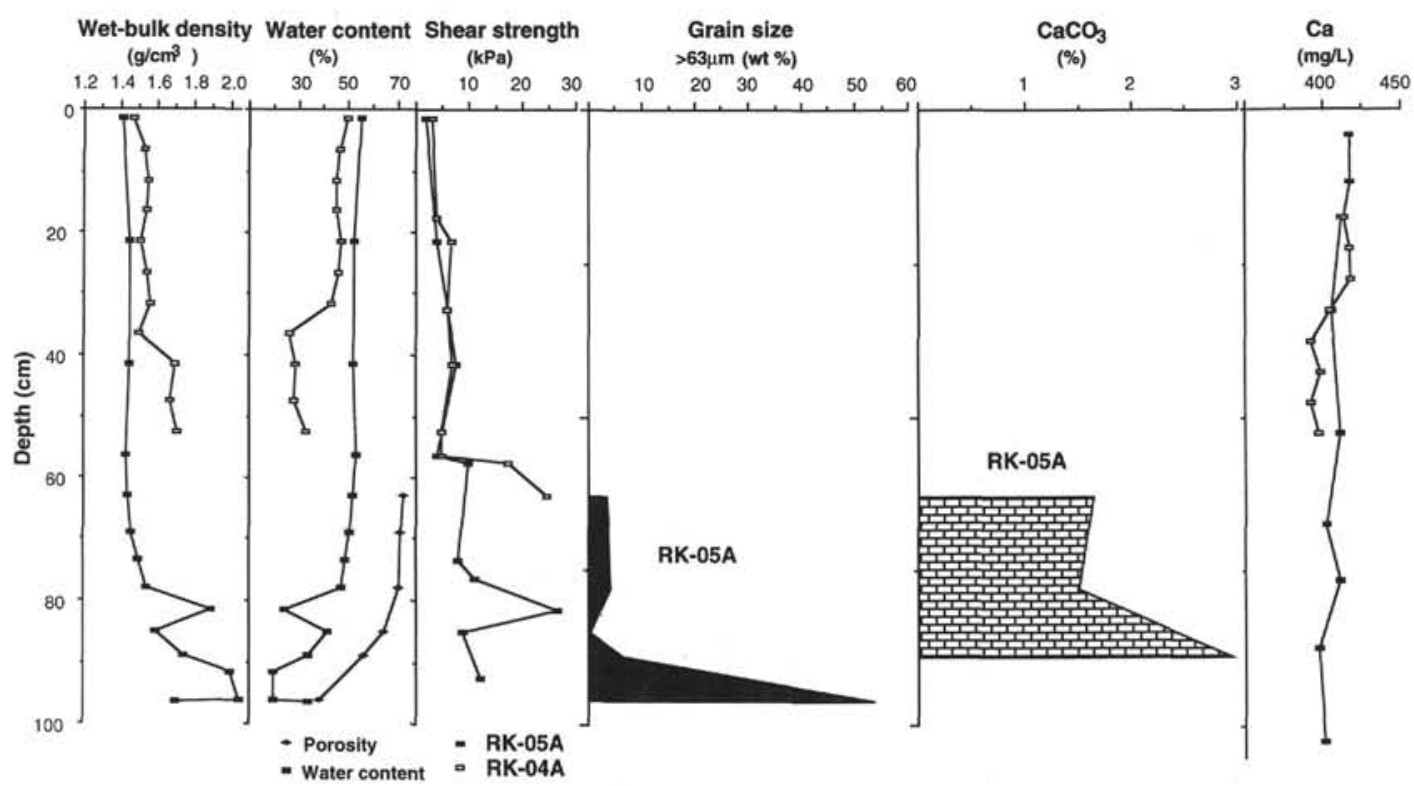

Figure 7. Physical properties of Core W8306C-11 reflect the unconsolidated nature of the sediments within a sediment pond situated between two deformational ridges. Dissolved calcium values in the pore water are those reported by Han (1987).

cores at various depths. A surprising result is the homogeneity of the bulk mineralogy of the sediments recovered from the various tectonic environments and water depths; this finding implies that differences in burial depth and degree of consolidation have no influence upon the mineralogical composition and that the provenance does not vary greatly. X-ray diffractograms reveal quartz to be by far the most dominant lithogenic component, with maximum intensities of the 101peak $(\mathrm{d}=3.433 \AA)$. Feldspar and clay minerals were identified in all samples. The clay fraction is dominated by muscovite and chlorite. Dolomite was documented by a 104-peak ( $d=2.882 \AA)$ in samples from Cores AT8408-04, AT8408-11, and W8306A-05. The first two cores are located in the deformation front area, whereas the third is from an active vent site (Suess and Whiticar, 1989). Dolomite presumably forms by precipitation from methane- and $\mathrm{CO}_{2}$-containing pore fluids. The dolomite is restricted to compacted, coarse-grained (silty sand to fine sand) layers that in turn suggest pathways of high permeability that may be closely related to venting processes (Ritger et al., 1987).

Carbonate contents are consistently below $10 \mathrm{wt} \%$; nevertheless, there is a difference between the deformed and undeformed sediments. The carbonate content in the undeformed sediments from the abyssal plain and from sediment basins separating the ridges range from $6 \%$ to $9 \%$. Carbonate contents in the deformed sediments reach maximum values of $3 \%$.

\section{Sedimentation Rates at the Continental Slope off Oregon}

Determination of sedimentation rates on the continental margin off northwestern America is hampered by the difficulty of dating the sediments either biostratigraphically or by oxygen isotopes. The oc- 


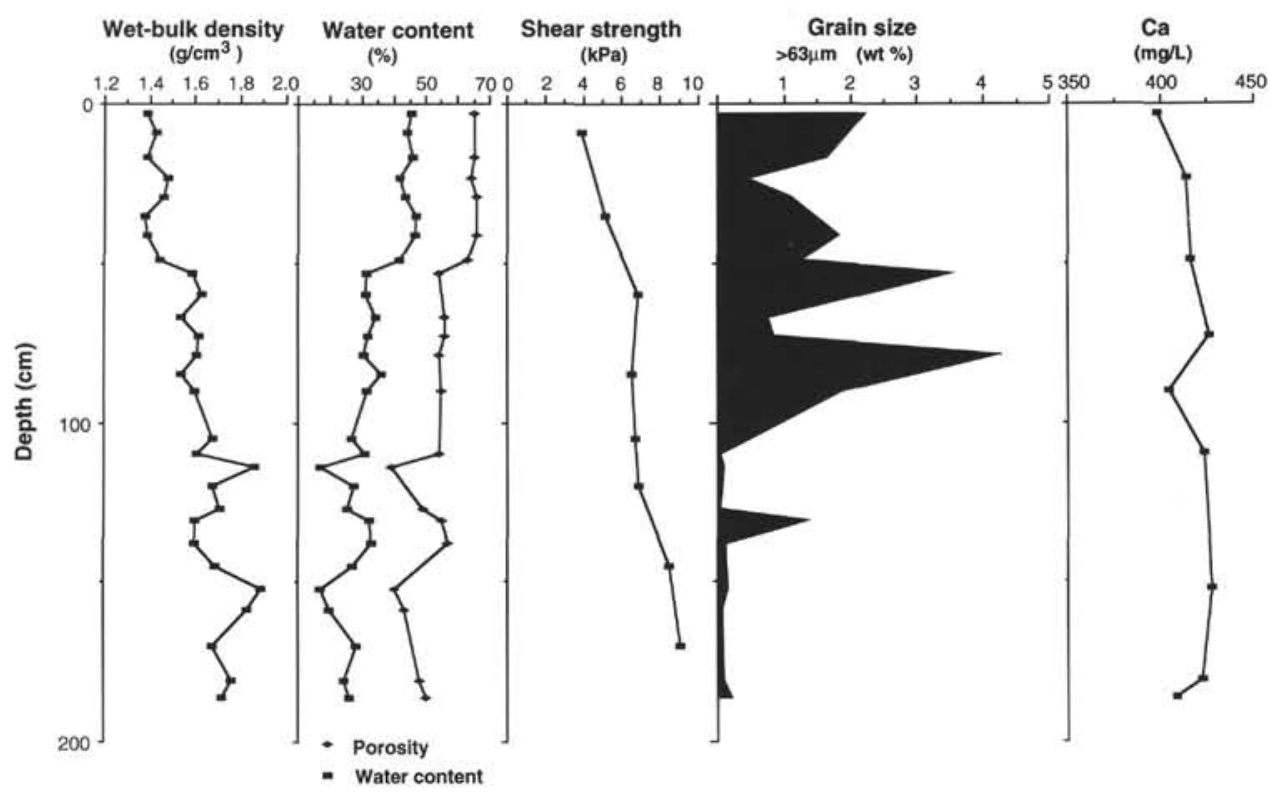

Figure 8. The Cores W8306A-04/-05 were recovered from the western slope of the second deformation ridge. The physical properties show only minor tectonic influence on the recovered sediments. Dissolved calcium values in the pore water are those reported by Han (1987).

currences of foraminifers are too sparse to establish a reliable oxygen isotope record by conventional mass spectrometry. The need of about $250 \mathrm{~g}$ of sediment (due to an organic content of about only $1 \%$ ) to obtain a single date with standard ${ }^{14} \mathrm{C}$ methodology considerably restricted the time resolution. The samples for ${ }^{14} \mathrm{C}$ dating must span an interval of about $8 \mathrm{~cm}$ in the cores to obtain a sufficient amount of organic carbon. Samples of Core AT8408-11 from the abyssal plain, just in front of the deformation front, were used for ${ }^{14} \mathrm{C}$ dating and the subsequent calculation of sedimentation rates.

The age-depth profile extends to a depth of $106 \mathrm{~cm}$, corresponding to about 7,200 yr B.P. and results in a mean sedimentation rate of $27.5 \mathrm{~cm} / \mathrm{k} . \mathrm{y}$. for the uppermost $31 \mathrm{~cm}(4,000 \pm 100 \mathrm{yr}), 27.5 \mathrm{~cm} / \mathrm{k} . \mathrm{y}$. in the interval from 31 to $71 \mathrm{~cm}(5,500 \pm 110 \mathrm{yr})$, and about $20 \mathrm{~cm} /$ k.y. in the depth interval from $71 \mathrm{~cm}$ to $106 \mathrm{~cm}(7,200 \pm 130 \mathrm{yr})$. The sedimentation rate of $27.5 \mathrm{~cm} / \mathrm{k}$.y. for the last $4,000 \mathrm{yr}$ reflects the assumption of a ${ }^{14} \mathrm{C}$ age of $2,900 \mathrm{yr}$ for the surface sediments. The results are shown graphically in Figure 11 and listed in Table 3.

\section{Dewatering Along the Cascadia Margin}

The water contents of all samples from the 37 sediment cores from the Cascadia Margin were determined. Although the cores are spread over a distance of $350 \mathrm{~km}$ along the continental margin, they are all affected by the subduction of the Juan de Fuca plate beneath the North American plate. In most cores there exists a substantial difference in the water content between the unconsolidated and consolidated sections. High water contents characterize the silty and clayey muds and oozes, whereas lower water contents occur in the cemented silty to sandy layers. Figure 12 illustrates the loss of near-surface water through tectonic dewatering processes, which is calculated from the difference in water content between the undeformed and deformed sediments. Average water contents from sites of the abyssal plain were used as background values from which the water contents of the same depths within the cores located in deformed regimes were subtracted to yield the water loss. This simple calculation gives the amount of water expelled from these shallow sediments during the last $8,400 \mathrm{yr}$ of deformational stress. Accordingly, expulsion rates of $2 \times 10^{-4} \mathrm{~L} / \mathrm{m}^{2} /$ day $\left(2.3 \times 10^{-12} \mathrm{~m}^{3} / \mathrm{m}^{2} / \mathrm{s}\right)$ were obtained by using the maximal difference in water content of $30 \%$ between the undeformed

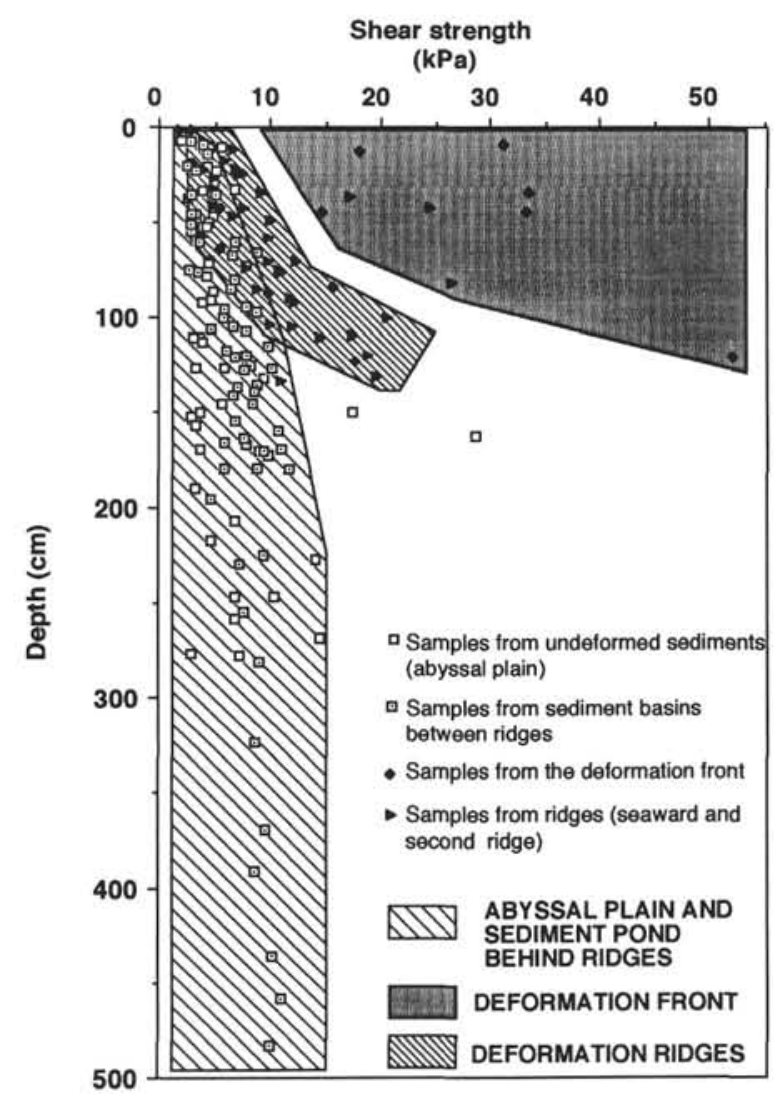

Figure 9. Shear strength vs. depth in relation to the tectonic environment. 


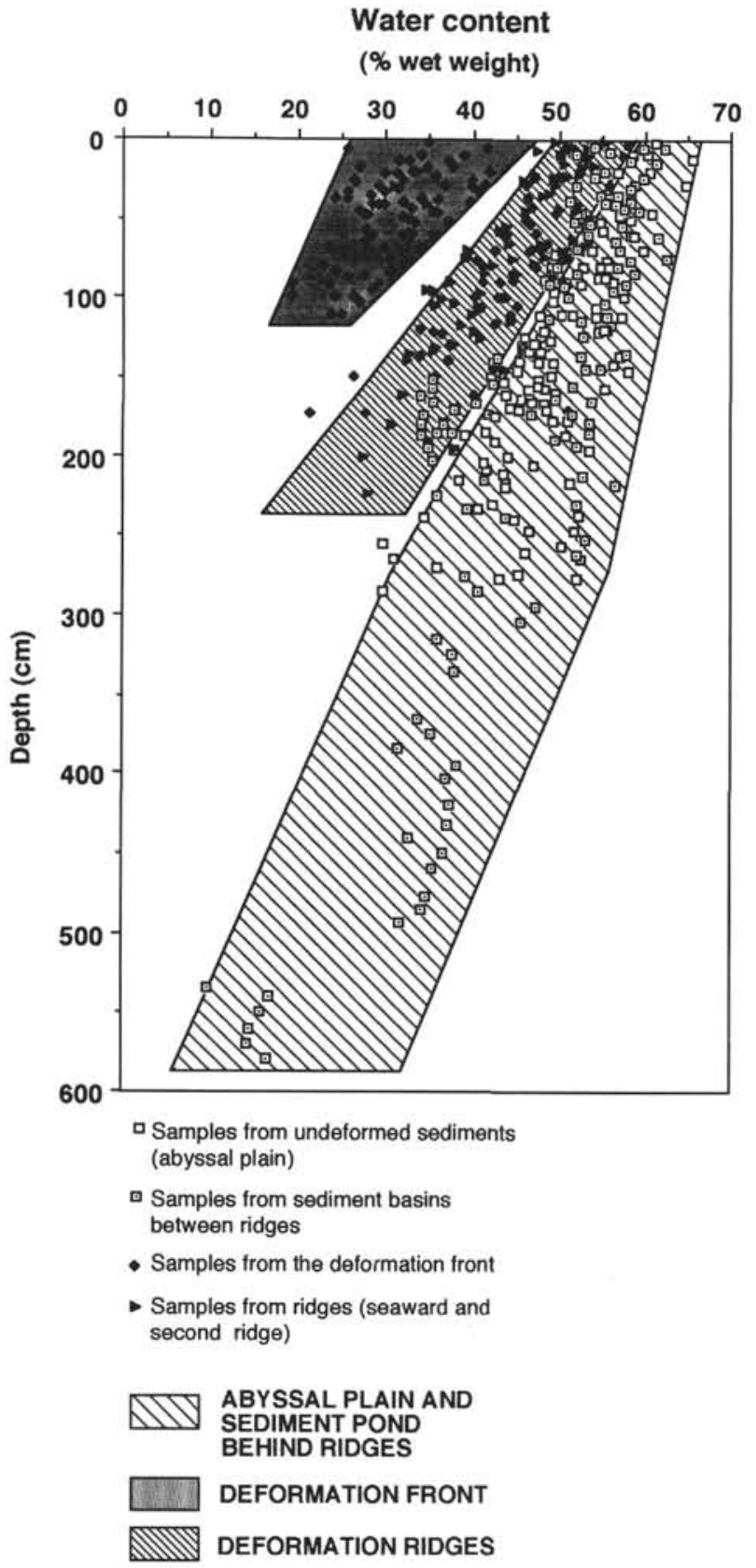

Figure 10. Water content vs. depth in relation to the tectonic environment.

and deformed sediments down to a depth of $2 \mathrm{~m}$, which ${ }^{14} \mathrm{C}$ dating suggests encompasses a time span of $8,400 \mathrm{yr}$. I consider these numbers an order of magnitude estimate, because one has to assume the same sedimentation rate, sedimentologic properties, and age-depth profile for all cores, although these were established at only one core.

\section{DISCUSSION}

\section{Pelagic Carbonate Deposition and Authigenic Carbonate Precipitation}

Our carbonate analyses and those of Scamman (1981) from surface samples of the same area, combined with carbon isotopic analyses, give insight into the origin of carbonates in this hemipelagic and tectonic environment. The carbon isotopic values can be separated into six groups (Fig. 13). There is a clear frequency maximum in Group II ( 0 to $-3 \%$ PDB) representing samples containing modern benthic foraminifers with an isotopic composition of $+0.5 \%$ to $-1 \%$ o PDB typical for this region (R. Zahn, pers. comm., 1993). Group VI, with $\delta^{13} \mathrm{C}$ values of $-40 \%$ to $-70 \%$ PDB, represents carbonates derived from the oxidation of a mixture of thermogenic and biogenic methane (Suess and Whiticar, 1989). Groups III and IV with $\delta^{13} \mathrm{C}$ values of $-6 \%$ to $-20 \%$ PDB are present in minor amounts, and samples with carbon isotopic signatures of $-20 \%$ to $-40 \%$ PDB are absent. The division of $\delta^{13} \mathrm{C}$ groups can be related directly to differences in the amounts of carbonate present in the samples. The most common carbonate contents correspond to Group III and not Group II as do the $\delta^{13} \mathrm{C}$ isotopic values. In all other groups there is agreement between the frequency distribution of carbonate content and the isotopic signatures (Fig. 13). Figure 14 shows the carbonate contents and $\delta^{13} \mathrm{C}$ isotopic ratios of samples from two adjacent dredge hauls (Fig. 15). Dredge 19 is typical of Group II with carbonate contents up to $6 \%$ and $\delta^{13} \mathrm{C}$ values of $0 \%$ to $-3 \%$ PDB. Samples of dredge 16 show that high carbonate contents of up to $60 \%$ correspond with light $\delta^{13} \mathrm{C}$ values of $-50 \%$ PDB, which is characteristic for Group VI.

The correspondence of $\delta^{13} \mathrm{C}$ values with the carbonate contents of the surface samples is used to infer the isotopic ratios from the carbonate contents measured in the sediment cores, as isotopic analyses have not been yet performed on samples from the sediment cores. The frequency distribution of carbonate contents obtained from the cores shows a maximum in Groups I and II ( $0-5 \mathrm{wt} \%$ carbonate). The corresponding carbon isotopic ratios are inferred to be between $+1 \%$ o and $-3 \%$ PDB, which would indicate that the carbonate is almost exclusively biogenically produced. Carbonate contents between $5 \%$ and $10 \%$ (Group III), reflecting carbon isotopic values of $-3 \%$ o to $-5 \%$ PDB, are present only in single samples, and carbonate contents of $>10 \%$ are completely missing. These carbonate characteristics imply that there is no methane-derived carbonate present in disseminated form in the cores. This result does not exclude possible authigenic carbonate production, because higher carbonate contents could be dissolved by interaction with the pore waters, or might not be sampled by coring.

\section{Origin of Cemented Layers}

A typical phenomenon in a great number of cores from the Cascadia subduction zone is the appearance of partially cemented layers at various depths. On several occasions these layers prevented deeper penetration of the coring device. The cemented layers can be recognized in the visual core description as well-defined horizontal layers of up to $20-30 \mathrm{~cm}$ thick. They are composed of a higher amount of the coarse fraction than the surrounding soft silty to clayey sediments. Grain-size analyses support the macroscopic observation of an upward gradation from coarser to finer detrital particles within the cemented layers. XRD analyses performed on samples from the uncemented and cemented sediments exhibit a great similarity in bulk mineralogy. Bulk mineralogy seems to be unaffected by the degree of cementation, as there are only minor differences in the overall mineralogical composition and in the refraction intensities of single minerals. The carbonate contents tend to be slightly higher in the cemented layers compared with the surrounding sediments.

A possible mechanism to generate the cemented layers may be seen in their close genetic relationship to venting processes. In Figures $16 \mathrm{~A}$ through $16 \mathrm{D}$ the generation of a cemented layer in the context of venting is schematically illustrated. The typical seafloor setting in a venting area shown in Figure 16A summarizes observations made during submersible dives (i.e., the presence of colonies of tubeworms associated with clam fields and carbonate chimneys; Fig. 16A; Suess et al., 1985; Ritger et al., 1987). Within the seabed there are randomly distributed cemented lenses (concretions, slabs) of coarse-grain sediments at different depths and of various lateral extents. Slight motions along locally restricted (and possibly numerous) 


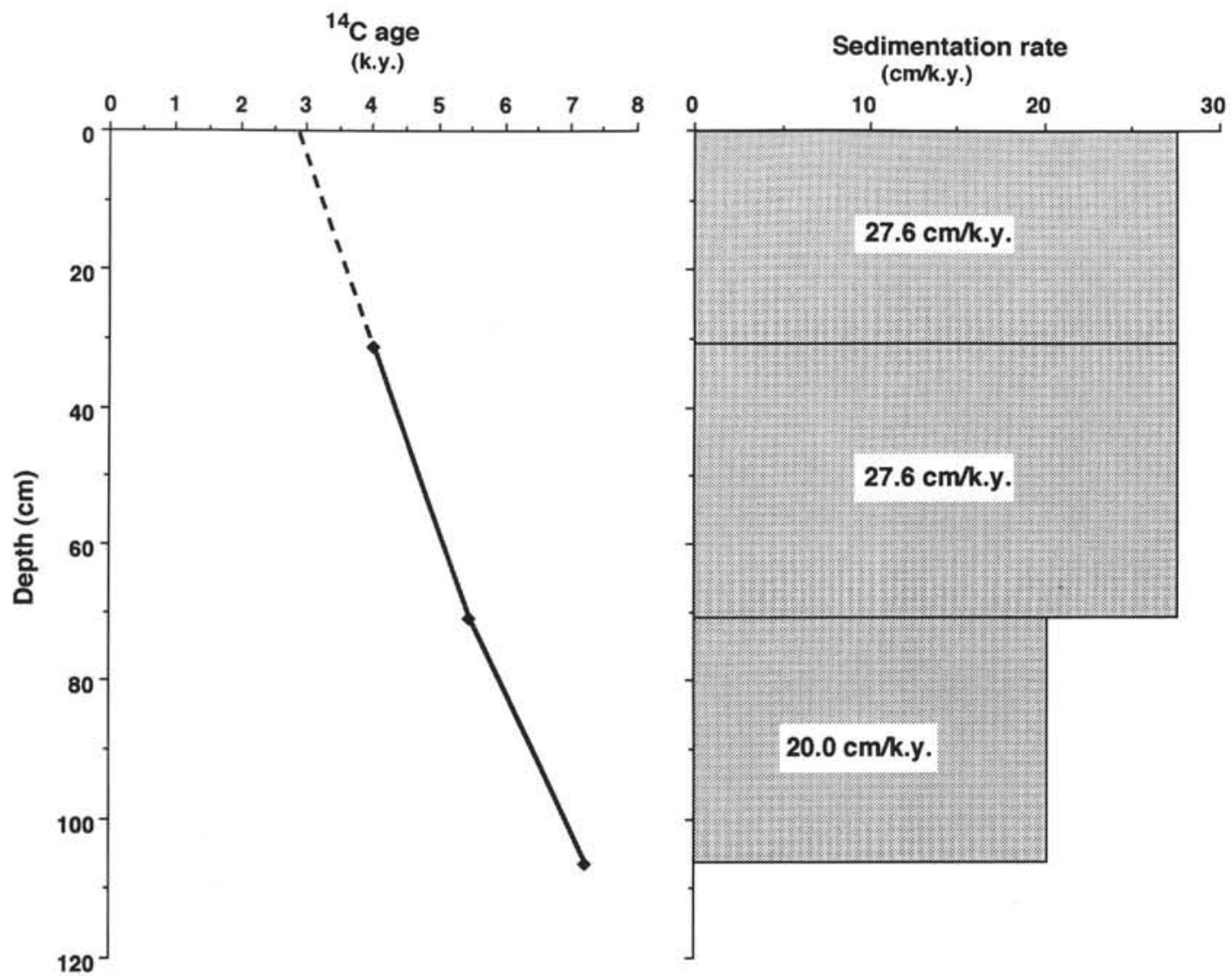

Figure 11. Age-depth profile derived from ${ }^{14} \mathrm{C}$ dating of samples from Core AT8408-04 and the calculated sedimentation rates.

faults allow the upward migration of fluids and dissolved gases in the accretionary complex and their subsequent expulsion at the seafloor. With the presumably sudden onset of venting, the fine sediment particles are preferentially suspended (Fig. 16B), and the coarser components remain at the site. Vent organisms are attracted and settle at the new site of nutrient supply (Fig. 16C). The flow rates remain relatively constant over an as yet unknown time span before the onset of a slow decline (Fig. 16C). This decrease in flow leads to an upward mixing of coarse remnant particles and pelagic sedimentation, which result in gradational bedding at the vent site and its vicinity. In Figure $16 \mathrm{D}$ the coarse-grained layer is illustrated as part of the sediment column.

In this scenario the cementation of the sediments within the presumably lense-shaped graded layer is a syn- and post-sedimentary process, caused by authigenic carbonate precipitation of $\mathrm{\Sigma CO}_{2}$ - and $\mathrm{CH}_{4}$-containing fluids. This precipitation is expressed by the occurrence of dolomite in some of the cemented layers (Fig. 17). Longterm expulsion of these fluids results in the generation of carbonate chimneys and concretions of various shapes and sizes at the seafloor as observed on submersible dives (Ritger et al., 1987) and dredged by fishermen.

The coarse-grained layers do not necessarily originate from turbidite deposition, but may be generated by venting processes. This genesis is evident from the coincidence of a higher degree of consolidation of the layers and the restricted occurrence of dolomite to these layers. It also has to be considered that the precipitation of dolomite is favored along natural layers of coarser sediments, such as the base of turbidites. Nevertheless, Cores AT 8408-04 and AT 8408-11 are separated by only about $200 \mathrm{~m}$ but reveal cemented layers at different sub-bottom depths (Fig. 18). Over this distance, the turbiditic events should be preserved in both cores at least as the same number of layers and at the same depths, unless faulting has offset the sequence. In situ observations from submersibles show that in an area of venting activity, single vent sites are only a few meters across and separated by tens of meters. The two cores have presumably sampled individual vent sites, which have been active at different times.

The estimated dispersed expulsion rate agrees within one order of magnitude with those based on porosity reduction published by Carson et al. (1990). The expulsion rates calculated from porosity reduction are four to five orders of magnitude smaller than those obtained by direct flow measurements in venting areas (Linke et al., 1994). This difference presumably is related to the unknown area of focused venting at the deformation front (e.g., whether $0.1 \%, 1.0 \%$, or $10 \%$ of the total area from which the sediment cores were taken is actively venting). On the other hand, the direct fluid-flow measurements made by submersible were always taken at the highly focused vent sites and thus are biased toward active venting areas. A further uncertainty with the calculation of expulsion rates is related to possible recirculation within the uppermost sediment column (Henry et al., 1992).

Table 3. Sedimentation rates of Core AT8408-04, calculated from conventional ${ }^{14} \mathrm{C}$ dates on the total carbon content.

\begin{tabular}{ccc}
\hline $\begin{array}{c}\text { Depth } \\
(\mathrm{cm})\end{array}$ & $\begin{array}{c}\text { Age } \\
(\mathrm{yr})\end{array}$ & $\begin{array}{c}\text { Sedimentation rate } \\
(\mathrm{cm} / \mathrm{k} . \mathrm{y} .)\end{array}$ \\
\hline 31 & $4,010 \pm 100$ & \\
71 & $5,460 \pm 110$ & 27.560 \\
106.5 & $7,230 \pm 130$ & 20.060 \\
\hline
\end{tabular}




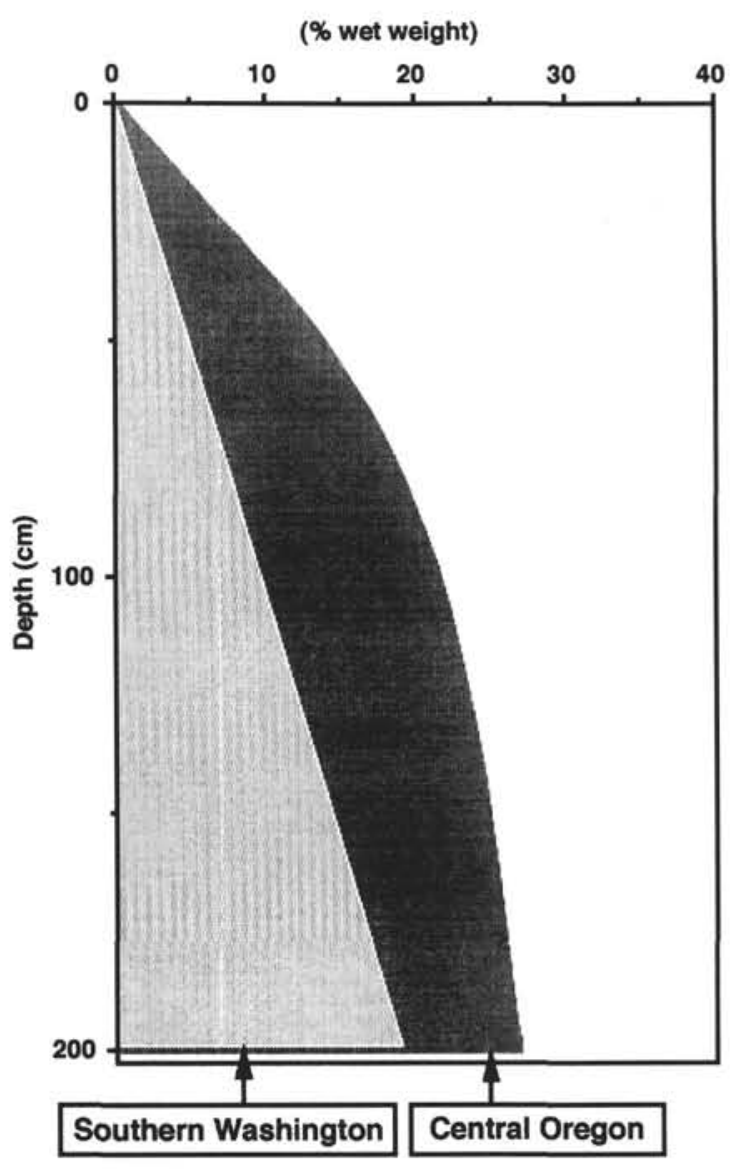

Figure 12. Dewatering of the sediments as a consequence of deformation along the Cascadia subduction zone. The difference in water content in percent wet-weight between the undeformed sediments of the abyssal plain and the deformed sediments of the deformation area indicates a considerably higher amount of dewatering off central Oregon compared to the sites off southern Washington.

The overall trend of physical properties allows the assumption that the present-day migration of fluids from depth to the seafloor occurs within the minor consolidated sediment intervals and is hampered by the cemented coarse-grained layers. This hypothesis can be confirmed by permeability tests, which unfortunately, could not be conducted on the available samples. Nevertheless, the main transport of fluids and gases within the accretionary prism occurs along the numerous fault planes (Wang et al., 1990) and, to a reduced degree, within the sediment strata.

\section{CONCLUSIONS}

Physical properties of sediments recovered by gravity cores from the Cascadia Margin reflect the effects of deformational processes along this convergent margin. Highest compaction states occur presently at the front of deformation expressed by abnormally high shear strength values and low porosity values, even at shallow burial depths. Older deformation ridges exhibit values differing significantly from those obtained from the undeformed sediments present on the abyssal plain and in the basins between the deformation ridges.

Physical property measurements combined with grain-size, carbonate, and bulk mineralogy analyses provided a comprehensive data set to verify the composition of the cemented layers encountered at different depths in numerous cores. There appears to be a coincidence of coarser (silty to sandy) sediments with high shear strength and lower water content compared with the otherwise homogeneous clayey to silty unconsolidated intervals. Despite few occurrences of dolomite in some of the cemented layers, there is no difference in the bulk mineralogy between the uncemented and cemented sediments. Quartz, felspar and clay minerals (illite and chlorite) are the dominant lithogenic components. Carbonate contents between $1 \%$ and $3 \%$ are most common with single samples reaching values of up to $10 \%$. Apart from the highly homogeneous mineralogical composition, dolomite was detected in some of the cemented layers, and is presumably a precipitation product of the $\mathrm{CO}_{2}$-containing fluids expelled.

Based on the observations from the numerous cores, a model for the generation of the cemented, coarse-grained and graded layers was developed. Because these intervals appeared at two adjacent cores in different depth intervals, we conclude that they are derived from venting processes and are not deposited by turbidity current events.

By comparing the water contents of the cores from the undeformed abyssal plain and the deformed part of the continental margin, it was possible to estimate the water expulsion rate during the deformation process to be $2 \times 10^{-4} \mathrm{~L} / \mathrm{m}^{2} / \mathrm{yr}\left(2.3 \times 10^{-12} \mathrm{~m}^{3} / \mathrm{m}^{2} / \mathrm{s}\right)$. Dewatering is enhanced off central Oregon compared to the margin off southern Washington. To obtain an idea about the rates of sedimentation along the Cascadia Margin for the uppermost sediments, we dated an undisturbed core recovered from the abyssal plain close to the deformation front. ${ }^{14} \mathrm{C}$ dates yield sedimentation rates of $20.6 \mathrm{~cm} / \mathrm{k}$.y. to $27.5 \mathrm{~cm} / \mathrm{k} . \mathrm{y}$. for the last $7,200 \mathrm{yr}$ B.P.

\section{ACKNOWLEDGMENTS}

I would like to acknowledge the most helpful assistance of A. Ungerer during sampling at the core repository at Oregon State University, Corvallis. The sediment cores were collected between 1983 and 1987 with financial support through NSF Grant OCE-86-09789 to L.D. Kulm (OSU) and E. Suess. Financial support to the core repository at OSU is provided by NSF grant No. OCE88-00458. Physical property measurements were conducted with the help of S. Utschakowski and U. Peters at GEOMAR, Kiel. I would like to express my sincere appreciation to P. Holler and F. Kögler (Univ. of Kiel), who made the shear strength device available. Many thanks are due to $G$. Bohrmann and the technical staff of the Alfred-Wegener-Institute for Polar and Marine Research (Bremerhaven) for performing the XRD measurements. I thank H. Willkomm and the staff of Radiocarbon Laboratory (Univ. of Kiel) for the ${ }^{14} \mathrm{C}$ dating, as well as J. Killingley (formerly Scripps Institution of Oceanography) for stable isotope measurements. I most gratefully acknowledge the critical and helpful comments of M. Torres (Geomar), which improved the manuscript considerably. I am indebted to B. Carson, W. Brückmann, and E. Taylor for their constructive reviews. Financial support for this investigation was provided by BMFT-grant $03 R 6076$.

\section{REFERENCES}

Behrmann, J.H., Lewis, S.D., Musgrave, R.J., et al., 1992. Proc. ODP, Init. Repts., 141: College Station, TX (Ocean Drilling Program).

Boyce, R.E., 1976. Definitions and laboratory techniques of compressional sound velocity parameters and wet-water content, wet-bulk density, and porosity parameters by gravimetric and gamma-ray attenuation techniques. In Schlanger, S.O., Jackson, E.D., et al., Init. Repts. DSDP, 33: Washington (U.S. Govt. Printing Office), 931-958.

Bray, C.J., and Karig, D.E., 1985. Porosity of sediments in accretionary prisms and some implications for dewatering processes. J. Geophys. Res., 90:768-778.

Carson, B., 1977. Tectonically induced deformation of deep-sea sediments off Washington and northern Oregon: mechanical consolidation. Mar. Geol., 24:289-307.

Carson, B., Holmes, M.L., Umstattd, K., Strasser, J., and Johnson, H.P., 1991. Fluid expulsion from the Cascadia accretionary prism: evidence 
from porosity distribution, direct measurements, and GLORIA imagery. Philos. Trans. R. Soc. London A, 335:331-340.

Carson, B., Suess, E., and Strasser, J.C., 1990. Fluid flow and mass flux determinations at vent sites on the Cascadia margin accretionary prism. $J$. Geophys. Res., 95:8891-8897.

Davis, E.E., Horel, G.C., MacDonald, R.D., Villinger, H., Bennett, R.H., and $\mathrm{Li}, \mathrm{H} ., 1991$. Pore pressures and permeabilities measured in marine sediments with a tethered probe. J. Geophys. Res., B4:5975-5984.

Davis, E.E., and Hyndman, R.D., 1989. Accretion and recent deformation of sediments along the northern Cascadia subduction zone. Geol. Soc. Am. Bull., 101:1465-1480.

EEZ Scan 84 Scientific Staff, 1986. Atlas of the Exclusive Economic Zone, Western Conterminous United States. U.S. Geol. Surv., Misc. Investigations Ser., I-1972.

Han, M.W., 1987. Dynamics and chemistry of pore fluids in marine sediments of different tectonic settings: Oregon subduction zone and Bransfield Strait extensional basin [Ph.D. thesis]. Oregon State University, Corvallis.

Han, M.W., and Suess, E., 1989. Subduction-induced pore fluid venting and the formation of authigenic carbonates along the Cascadia continental margin: implications for the global Ca-cycle. Palaeogeogr., Palaeoclimatol., Palaeoecol., 71:97-118.

Henry, P., Foucher, J.-P., LePichon, X., Sibuet, M., Kobayashi, K., Tartis, P., Chamot-Rooke, N., Furuta, T., and Schultheiss, P., 1992. Interpretation of temperature measurements from the KAIKO-Nankai cruise: modelling of fluid flow in clam colonies. Earth Planet. Sci. Lett., 109:355-371.

Kulm, L.D., and Fowler, G.A., 1974. Oregon continental margin structure and stratigraphy: a test of the imbricate thrust model. In Burke, C.A., and Drake, C.L. (Eds.), The Geology of Continental Margins: New York (Springer), 261-284.

Kulm, L.D., and Suess, E., 1990. Relationship between carbonate deposits and fluid venting: Oregon accretionary prism. J. Geophys. Res., 95:8899-8915.

Kulm, L.D., Suess, E., Moore, J.C., Carson, B., Lewis, B.T., Ritger, S.D., Kadko, D.C., Thornburg, T.M., Embley, R.W., Rugh, W.D., Massoth, G.J., Langseth, M.G., Cochrane, G.R., and Scamman, R.L., 1986. Oregon subduction zone: venting, fauna, and carbonates. Science, 231:561566.

LePichon, X., Kobayashi, K., and Kaiko-Nankai Scientific Crew, 1992. Fluid venting activity within the eastern Nankai Trough accretionary wedge: a summary of the 1989 Kaiko-Nankai results. Earth Planet. Sci. Lett., 109:303-318.

Linke, P., Suess, E., Torres, M., Martens, V., Rugh, W.D., Ziebis, W., and Kulm, L.D., 1994. In situ measurement of fluid flow from cold seeps at active continental margins. Deep-Sea Res., 41:721-739.
MacKay, M.E., Moore, G.F., Cochrane, G.R., Moore, J.C., and Kulm, L.D., 1992. Landward vergence and oblique structural trends in the Oregon margin accretionary prism: implications and effect on fluid flow. Earth Planet. Sci. Lett., 109:477-491.

Mascle, A., Moore, J.C., et al., 1988. Proc. ODP, Init. Repts., 110: College Station, TX (Ocean Drilling Program).

Okada, H., 1989. Anatomy of trench-slope basins: examples from the Nankai Trough. Palaeogeogr., Palaeoclimatol., Palaeoecol., 71:3-13.

Ritger, S., Carson, B., and Suess, E., 1987. Methane-derived authigenic carbonates formed by subduction-induced pore water expulsion along the Oregon/Washington margin. Geol. Soc. Am. Bull., 98:147-156.

Scamman, R.L., 1981. Diagenetic carbonate cementation of clastic sediments near the sediment-water interface on the lower continental slope off Washington and northern Oregon [M.S. thesis]. Lehigh Univ., Bethlehem, PA.

Silver, E.A. 1972. Pleistocene tectonic accretion of the continental slope off Washington. Mar. Geol., 13:239-249.

Suess, E., Carson, B., Ritger, S., Moore, J.C., Jones, M., Kulm, L.D., and Cochrane, G., 1985. Biological communities at vent sites along the subduction zones off Oregon. In Jones, M.L. (Ed.), The Hydrothermal Vents of the Eastern Pacific: An Overview. Bull. Biol. Soc. Wash., 6:475-484.

Suess, E., von Huene, R., et al., 1988. Proc. ODP, Init. Repts., 112: College Station, TX (Ocean Drilling Program).

Suess, E., and Whiticar, M.J., 1989. Methane-derived $\mathrm{CO}_{2}$ in pore fluids expelled from the Oregon subduction zone. Palaeogeogr., Palaeoclimatol., Palaeoecol., 71:119-136.

Taira, A., Hill, I., Firth, J.V., et al., 1991. Proc. ODP, Init. Repts., 131: College Station, TX (Ocean Drilling Program).

Wang, C.-Y., Shi, Y., Hwang, W.-T., and Chen, H. 1990. Hydrogeologic processes in the Oregon-Washington accretionary complex. J. Geophys. Res., 95:9009-9023.

Westbrook, G.K., Carson, B., Musgrave, R.J., et al., 1994. Proc. ODP, Init. Repts., 146 (Pt. 1): College Station, TX (Ocean Drilling Program).

\section{Date of initial receipt: 6 September 1994 \\ Date of acceptance: 31 March 1995 \\ Ms 146SR-250}

\section{APPENDIX (on CD-ROM)}

Physical properties of all samples analyzed on board and at the shore-based laboratory up to seven years later. Note: Shipboard data lack porosity and grain density values. 

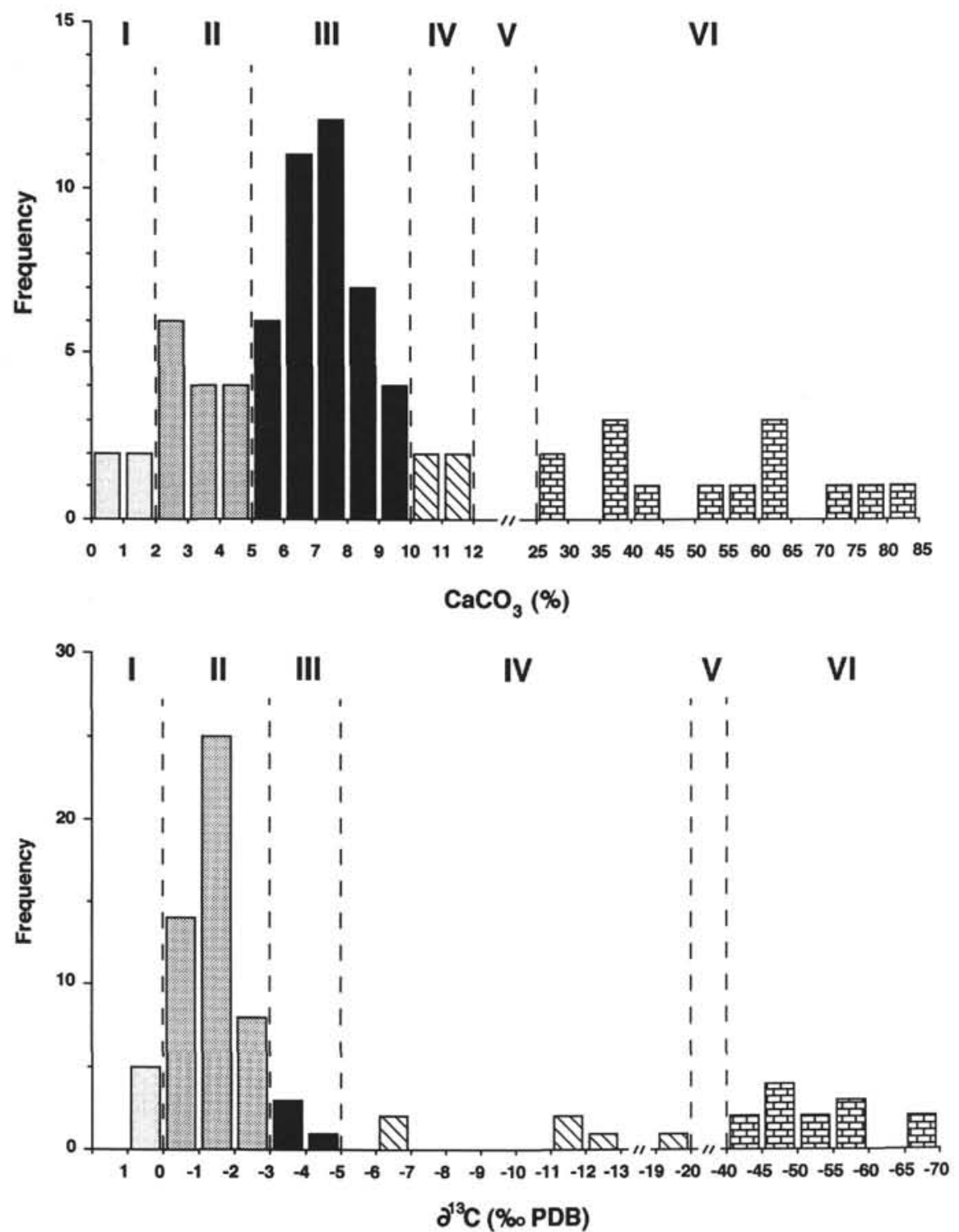

Figure 13. Relation and classification of $\mathrm{CaCO}_{3}$ content and $\delta^{13} \mathrm{C}$ values in samples of all anticipated tectonic environments along the Cascadia Margin. Some of the carbonate contents are from Scamman (1981). 

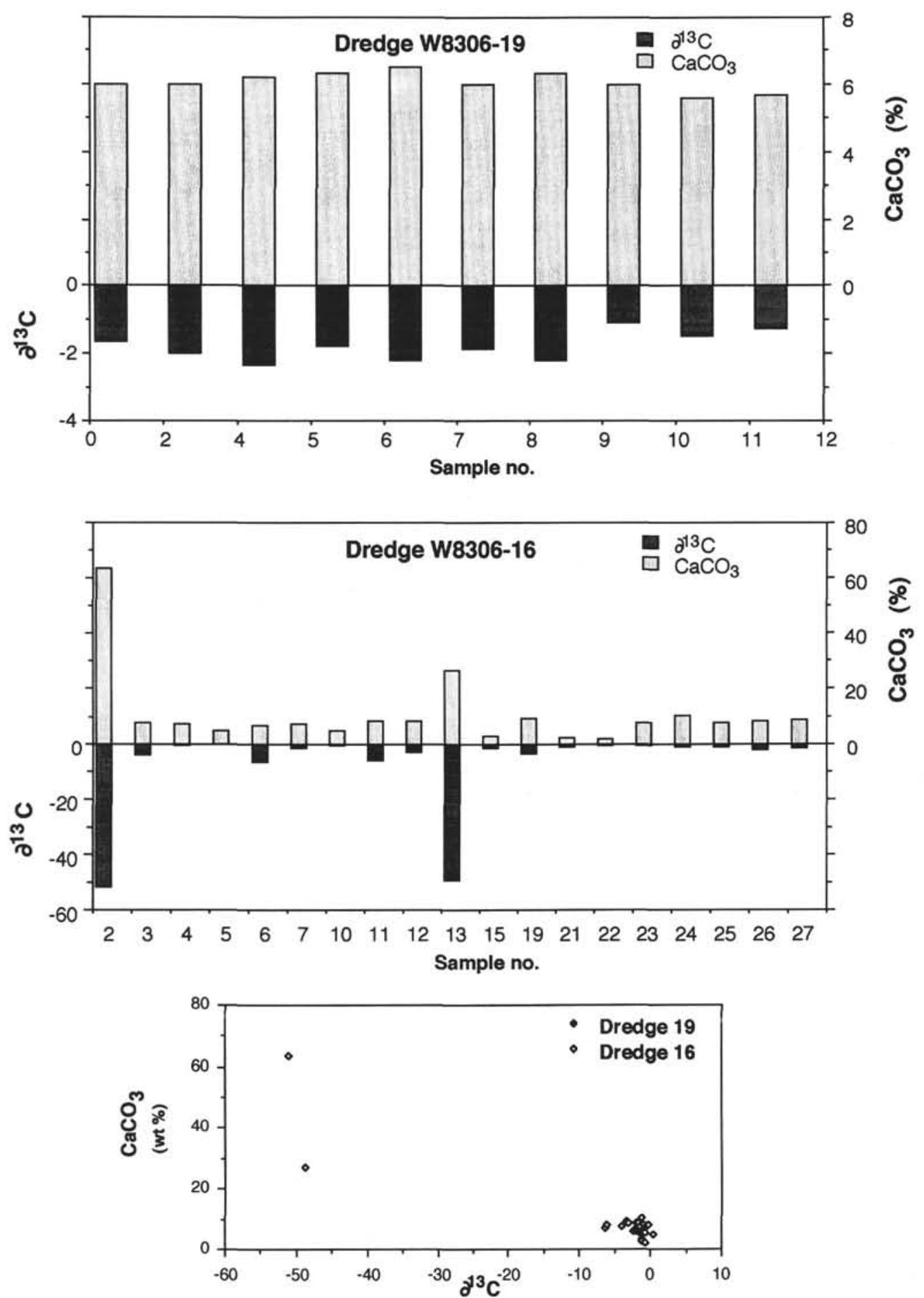

Figure 14. Comparison of carbonate contents and $\delta^{13} \mathrm{C}$ values of samples from dredge hauls 16 and 19. For location, see Figure 15. 
Positions of surface samples at the Oregon and Washington continental margin

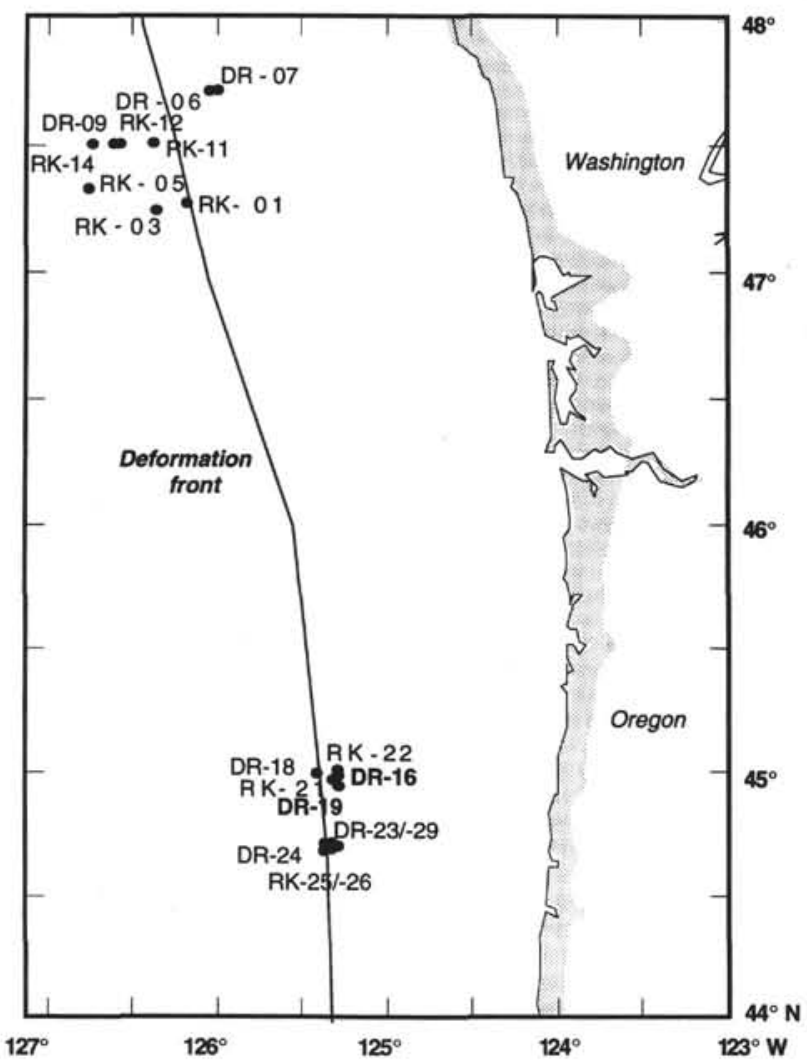

$\partial^{13} \mathrm{C}$ isotopes from surface samples

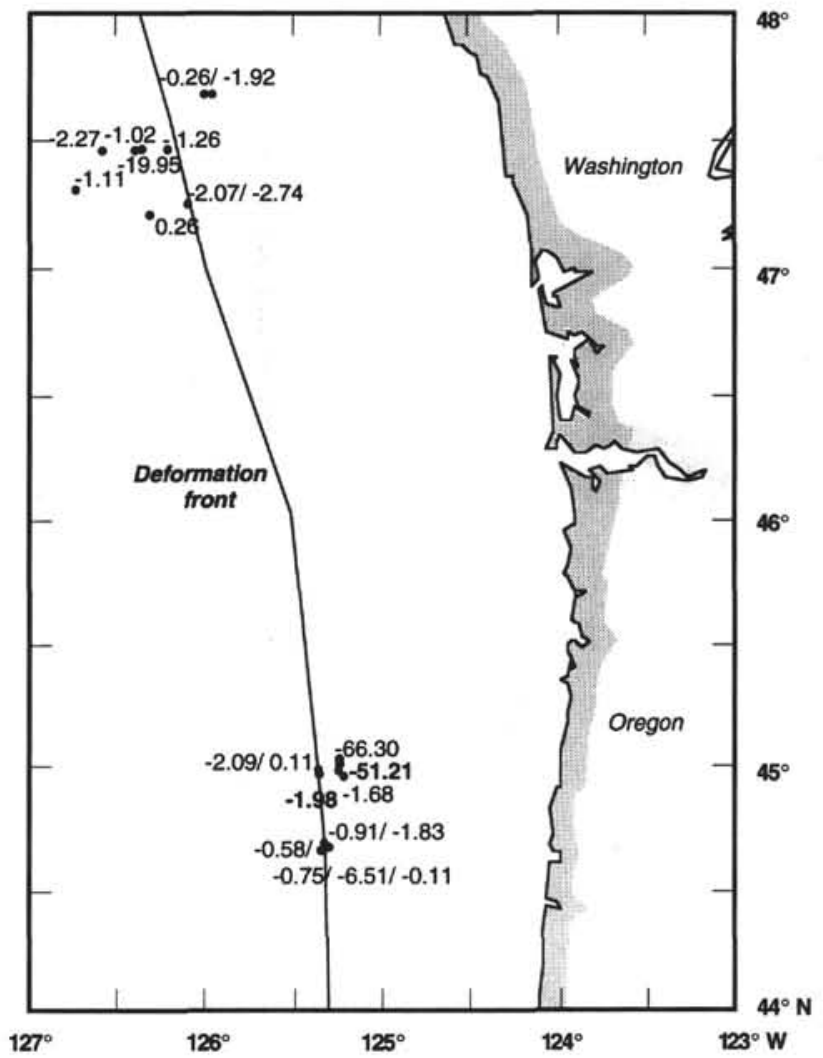

Figure 15. Location and $\delta^{13} \mathrm{C}$-values of surface samples from the Cascadia Margin. Location of deformation front after Davis and Hyndman (1989). 

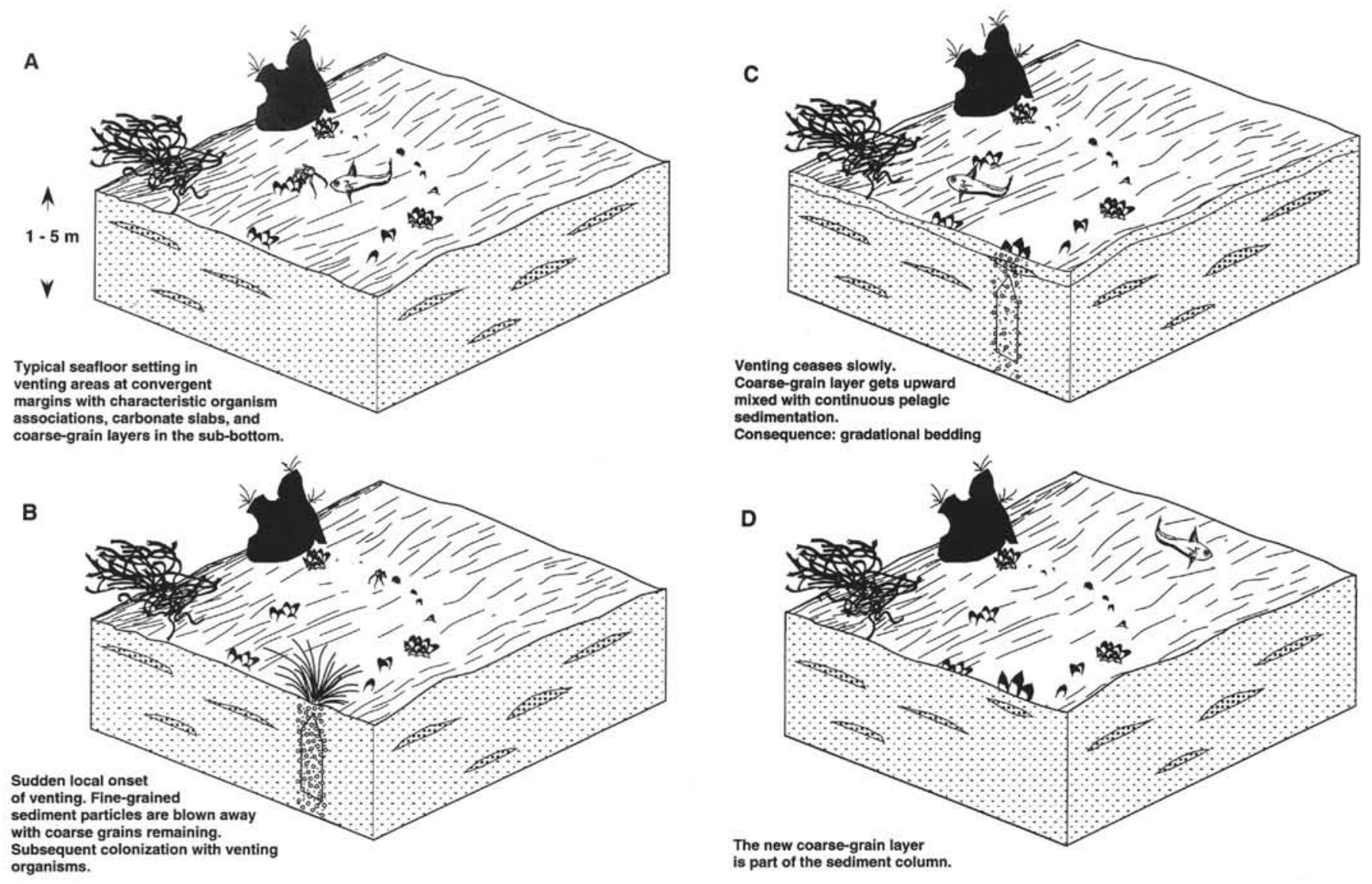

Figure 16. Diagrammatic illustration of the origin of cemented coarse-grained layers in venting areas. 


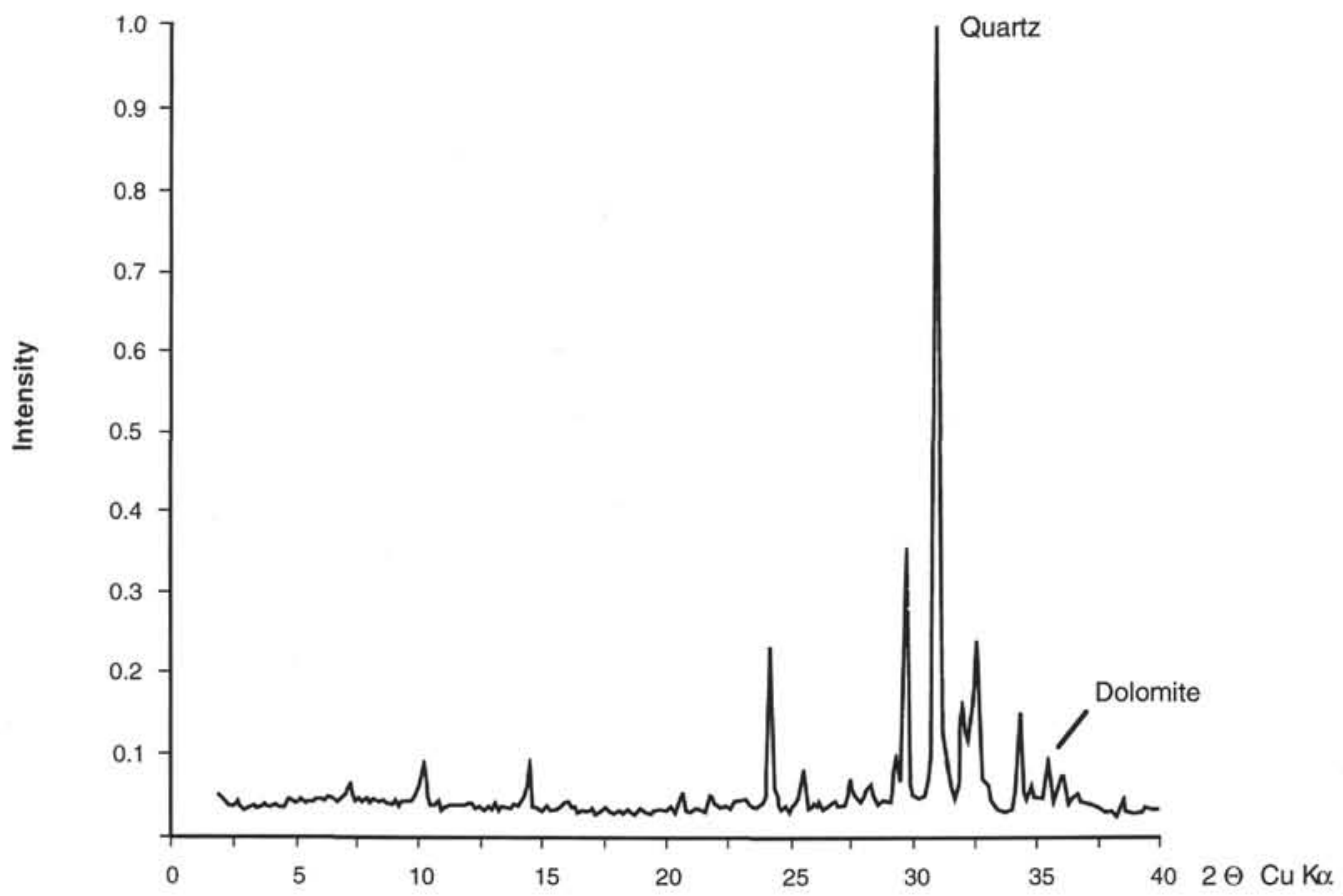

Figure 17. X-ray diffractogram of Sample AT8408-11, 114-116 cm, representing the mineralogic composition of a cemented layer with the high quartz intensity (occurring in all samples) of the 101-peak at $3.443 \AA 2 \Theta$. In addition this sample is characterized by a pronounced dolomite occurrence with the 104 -peak at $2.8859 \AA 2 \Theta$. 

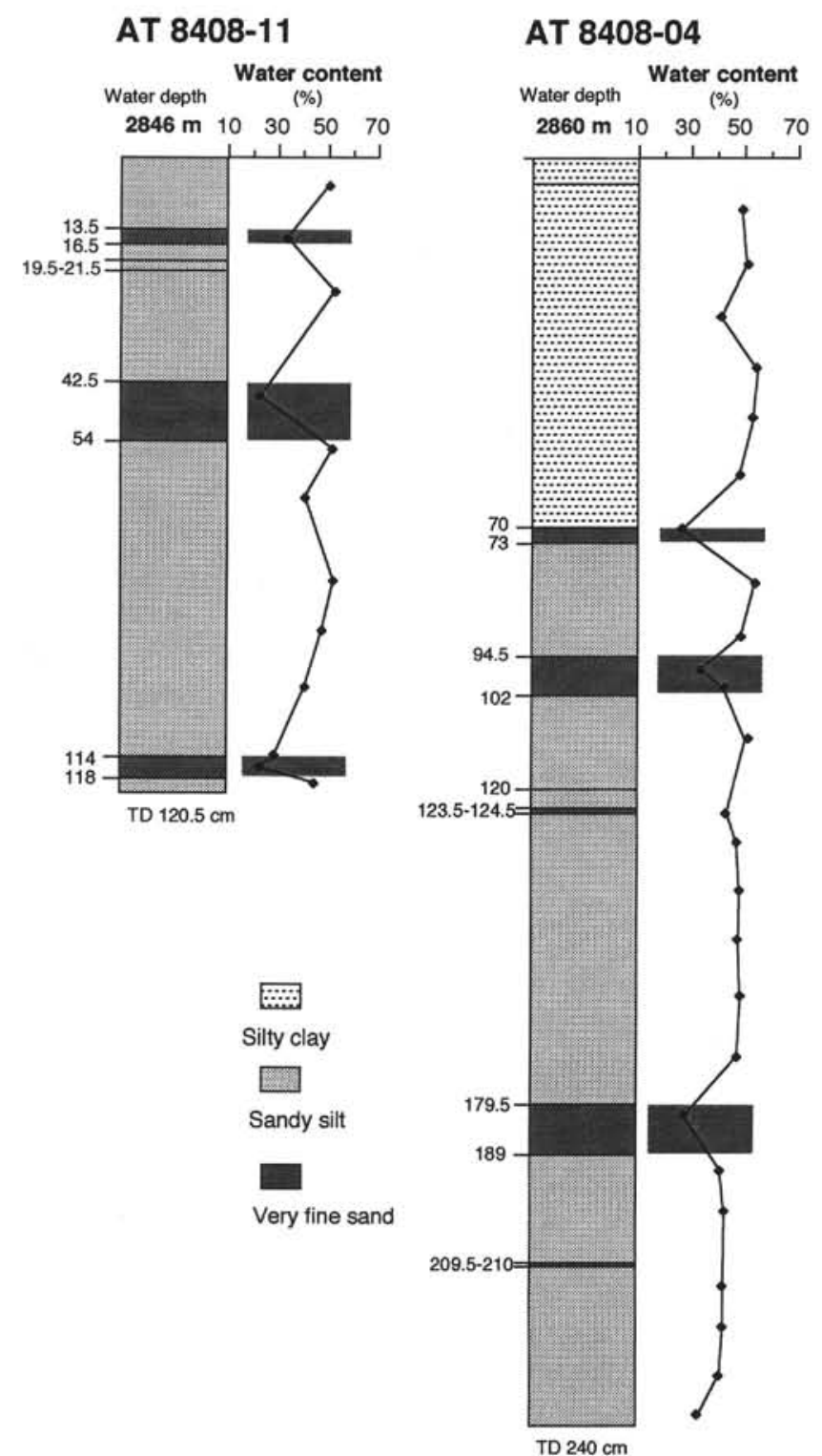

Figure 18. Lithology and water contents of Cores AT8408-04 and AT8408-11. The sites are separated by only about $200 \mathrm{~m}$, and thus the difference in depth of the cemented, coarse-grained layers is striking. This observation supports the idea that the layers did not originate from turbiditic events but instead are produced by venting, which is widespread along the margin but with a limited spatial extent of a single vent site. The water-content profiles reflect the lower values in the cemented layers relative to the unconsolidated sections. Therefore, present-day fluid flow takes place predominantly in the unconsolidated hemipelagic oozes and muds. 